Boise State University

ScholarWorks

Geosciences Faculty Publications and

Presentations

Department of Geosciences

2018

Petrology and Geochronology of Metamorphic Zircon

Matthew J. Kohn

Boise State University

Nigel M. Kelly

University of Colorado Boulder

This document was originally published in Microstructural Geochronology: Planetary Records Down to Atom Scale by Wiley on behalf of the American Geophysical Union. Copyright restrictions may apply. doi: 10.1002/

9781119227250.ch2 


\title{
2 \\ Petrology and Geochronology of Metamorphic Zircon
}

Matthew J. Kohn ${ }^{1}$ and Nigel M. Kelly ${ }^{2}$

\begin{abstract}
Zircon is unusually well suited for investigating metamorphic processes because it is readily analyzed for U-Pb ages, it harbors diverse mineral inclusions, and its chemistry can be linked to metamorphic parageneses and P-T paths. Metamorphic zircon chemistry and ages are relevant only at the sub-grain micron scale, and consequently many analytical methods, such as depth profiling, have been developed to exploit such spatially resolute information. Here we review how metamorphic zircon grows, and how its chemistry and inclusion assemblages may be used to link the age of a zircon domain to its metamorphic P-T condition. Domain-specific ages and inclusion assemblages from ultrahigh-pressure (UHP) zircons constrain rates of subduction and exhumation. Textures and chemistry of zircon and garnet from high- and ultrahigh temperature (UHT) rocks reveal petrogenetic implications of deep crustal heating, melting, and melt crystallization. Trace elements, inclusion assemblages, and oxygen isotopes in zircon show that dehydration reactions may catalyze zircon growth during subduction. Future research should include identifying natural systems that constrain diffusion rates, determining crystalchemical controls on trace element uptake in zircon and garnet for understanding how rare earth budgets and patterns change during metamorphism, and identifying underlying principles that govern the dissolution and reprecipitation of zircon during metamorphism.
\end{abstract}

\subsection{INTRODUCTION}

Zircon is perhaps the most commonly dated mineral to constrain metamorphic processes. Indeed, for this review, a literature search on the keywords "metamorphic zircon" retrieved over 5000 peer-reviewed articles. Although most of these contributions simply date zircon separates or overgrowths to provide broad constraints on the age of metamorphism, an increasing literature focuses on using zircon chemistry and inclusion assemblages to link in situ ages with metamorphic P-T conditions. Thus, investigation of zircon ages has shifted from analysis of

\footnotetext{
${ }^{1}$ Department of Geosciences, Boise State University, Boise, Idaho, USA

${ }^{2}$ Collaborative for Research in Origins (CRiO), Department of Geological Sciences, University of Colorado Boulder, Boulder, Colorado, USA
}

bulk zircon to the microanalysis of micron-scale domains using in situ techniques. We have divided this review into five sections of varying detail. First, we examine how metamorphic zircon forms. Because $\mathrm{Zr}$ stabilizes zircon, we especially consider $\mathrm{Zr}$ mass balance and processes that may redistribute $\mathrm{Zr}$ within a rock. Second, we examine how P-T conditions may be linked to zircon ages, emphasizing inclusion assemblages and zircon chemistry at the sub-grain scale. This topic, generically referred to as "petrochronology" or the marriage of petrology and geochronology, represents the fastest growing area of research today and is crucial to future investigations of metamorphic zircon. Third, we briefly cover the links between analytical strategies and methods of inferring P-T conditions. Fourth, we consider some key examples from diverse metamorphic terranes, including ultrahighpressure (UHP), ultrahigh-temperature (UHT), and "wet" environments. Last, we recommend future directions of study. While decades of research have

Microstructural Geochronology: Planetary Records Down to Atom Scale, Geophysical Monograph 232, First Edition. Edited by Desmond E. Moser, Fernando Corfu, James R. Darling, Steven M. Reddy, and Kimberly Tait. (C) 2018 American Geophysical Union. Published 2018 by John Wiley \& Sons, Inc. 
constructed a conceptual scaffold for interpreting zircon chemistry and ages, further study should be directed toward identifying what drives zircon dissolution and growth, and modeling its chemistry, to fulfill zircon's petrochronologic potential.

\subsection{HOW DOES METAMORPHIC ZIRCON FORM?}

Several mechanisms have been proposed for the formation of metamorphic zircon. The following sections discuss low-grade processes (Fig. 2.1a), retrograde release

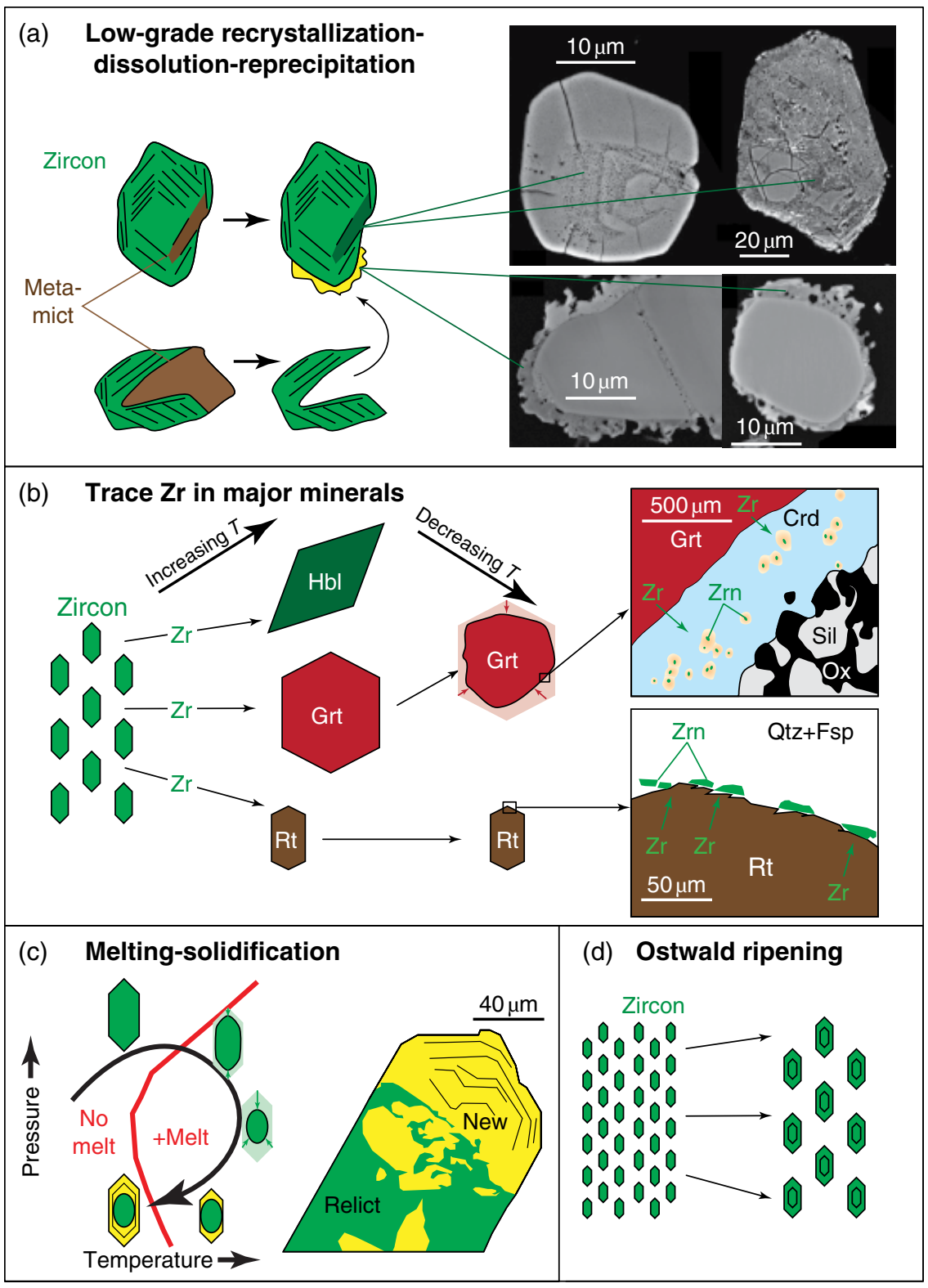

Figure 2.1 Mechanisms of zircon growth in metamorphic rocks. (a) At low grades, metamict zircon may recrystallize or dissolve and reprecipitate either within a crystal (upper images) or as overgrowths on other crystals (lower images). Images from Hay and Dempster [2009] with permission from Oxford University Press. (b) With increasing temperature, $\mathrm{Zr}$ contents of major and minor minerals increase. With decreasing temperature and/or retrograde dissolution, $\mathrm{Zr}$ is liberated and may form zircon. Sketches of natural rocks modified from Degeling et al. [2001] and Ewing et al. [2013]. (c) High Zr solubility in melts means that zircon dissolves during partial melting and reprecipitates during cooling. Sketch of leucosome zircon from Brouand et al. [1990]. (d) Ostwald ripening reflects the instability of small grains relative to large grains, due to high surface free energy contributions to total free energy in small grains. (See insert for color representation of the figure.) 
of $\mathrm{Zr}$ from major minerals (Fig. 2.1b), crystallization of in situ melts (Fig. 2.1c), and Ostwald ripening (thermodynamic instability of small grains relative to larger grains; Fig. 2.1d).

\subsubsection{Low-grade Processes}

Zircon has traditionally been viewed as "inert" at low metamorphic temperatures, with most research focused on zircon overgrowths formed at high-T and from crystallization of in situ partial melts. Pioneering work by Dempster and coworkers [Dempster et al., 2004, 2008; Hay and Dempster, 2009; Dempster and Chung, 2013] and Rasmussen [2005a, 2005b], however, first identified recrystallized zircon and zircon overgrowths in subgreenschist to greenschist-facies metamorphic rocks (Fig. 2.1a). These observations unequivocally document the stability of metamorphic zircon over a wide temperature range. Metamict zircon may recover at temperatures above ca. $225-250^{\circ} \mathrm{C}$ [Meldrum et al., 1999; Pidgeon, 2014], similar to the annealing temperature of fission tracks $\left(240 \pm 30^{\circ} \mathrm{C}\right.$; see Bernet and Garver [2005]), although the forms of radiation damage are not identical. Recrystallization of metamict zircon is complex, however [Nasdala et al., 2001, 2002], and some work has suggested that protracted periods at high temperatures are needed for full recovery under dry conditions, perhaps as long as $370 \mathrm{Ma}$ at $700^{\circ} \mathrm{C}$ [Geisler et al., 2001]. In contrast, aqueous experiments were interpreted as reflecting extensive dissolution and recrystallization of metamict zircon on laboratory time scales at temperatures as low as $300-360^{\circ} \mathrm{C}$ [Schmidt, 2006]. Thus, considering that most rocks contain a fluid phase during heating, the annealing textures documented in natural studies probably form in the lowest prehnite-pumpellyite to lower greenschist facies.

The efficacy of aqueous fluids in remobilizing zirconium (and hence zircon) during metamorphism remains an open question. Below $250-450^{\circ} \mathrm{C}$, preferential dissolution of metamict domains likely provides a source of $\mathrm{Zr}$ to form overgrowths [Schmidt, 2006]. The appearance of micro-zircon, included in metamorphic garnet, biotite and muscovite further suggests $\mathrm{Zr}$ mobilization at low-tomoderate metamorphic grades [Dempster et al., 2008]. Unusual fluid compositions may catalyze zircon dissolution and regrowth, particularly at high pressures [e.g., Sinha et al., 1992; Rizvanova et al., 2000; Liermann et al., 2002], and new observations for UHP rocks are beginning to link metamorphic zircon growth to dehydration reactions (see below). Conversely, experimental data suggest that low solubility of fully crystalline zircon in aqueous fluids buffered by various silicates [Wilke et al., 2012; Bernini et al., 2013] and low diffusion rate of high fieldstrength elements [Harrison and Watson, 1983; Koepke and Behrens, 2001; Baker et al., 2001; Bromiley and
Hiscock, 2016] prevent significant dissolution and mobility of zircon at most metamorphic conditions. Some studies also suggest that zircon is relatively inert during low- to moderate-pressure metamorphism [Williams, 2001; Vorhies et al., 2013].

\subsubsection{Solubility of $Z r$ in Other Minerals}

Most silicates contain extremely low concentrations of $\mathrm{Zr}$ (see summary in Kohn et al. [2015]) and do not directly affect growth or consumption of zircon. A few minerals, however, notably garnet, hornblende, and rutile, contain ppm-level concentrations of $\mathrm{Zr}$ that increase exponentially with increasing temperature $(1 \mathrm{ppm}=1 \mu \mathrm{g} / \mathrm{g}$; Fig. 2.1b) [Fraser et al., 1997; Degeling et al., 2001; Watson et al., 2006; Kohn et al., 2015]. Typical rocks contain ca. 100-200 ppm Zr, almost entirely ( $>99 \%$ ) hosted in zircon at low metamorphic grades. At elevated P-T conditions, however, rutile might occupy $1 \%$ of a rock by volume and contain $500-1000 \mathrm{ppm} \mathrm{Zr}$ (Fig. 2.2a). To provide this $\mathrm{Zr}$ to rutile, several percent zircon must dissolve. Similarly, if garnet and hornblende occur with modes of tens of percent and contain tens of ppm $\mathrm{Zr}$ [Degeling et al., 2001; Kelsey and Powell, 2011; Kohn et al., 2015], several percent zircon must again dissolve to source their $\mathrm{Zr}$. Thus, to maintain $\mathrm{Zr}$ mass balance, zircon must dissolve as temperature increases and as garnet, hornblende, and rutile first grow, then take up increasingly more $\mathrm{Zr}$ (Figs. 2.1b and 2.2). Because melts contain high concentrations of $\mathrm{Zr}$ (tens to hundreds of ppm) and can occupy up to tens of percent of rock volume, partial melting also drives zircon to dissolve (Figs. 2.1c and 2.2).

Mass balance models for $\mathrm{Zr}$ have been developed for various bulk compositions and along characteristic P-T paths (Fig. 2.2a-g) [Roberts and Finger, 1997; Kelsey et al., 2008; Kelsey and Powell, 2011; Yakymchuk and Brown, 2014; Kohn et al., 2015]. In pelitic rocks, subanatectic P-T paths ("Alpine" path; Fig. 2.2a) should dissolve only a few percent of zircon up to the peak of metamorphism, reforming a few percent zircon during exhumation and cooling (Fig. 2.2b and c). In contrast, unless zircon is protected as inclusions in stable minerals, several tens of percent zircon may dissolve along prograde paths that pass well into the partial melting field ("WGR" path, Fig. 2.2a, d, and e). Even paths that barely enter the melting field ("CC" path, Fig. 2.2a) may show significant zircon dissolution (Fig. 2.2f and g). If melts remain in the rock, as suggested by leucosome-melanosome textures, zircon is expected to reform during cooling and melt crystallization as overgrowths on older zircon nuclei [Roberts and Finger, 1997]. This theoretical prediction logically explains textures reported in migmatitic rocks. In paleosomes that have not interacted with melts and in mesosomes (restites), zircon appears rounded 
(a)

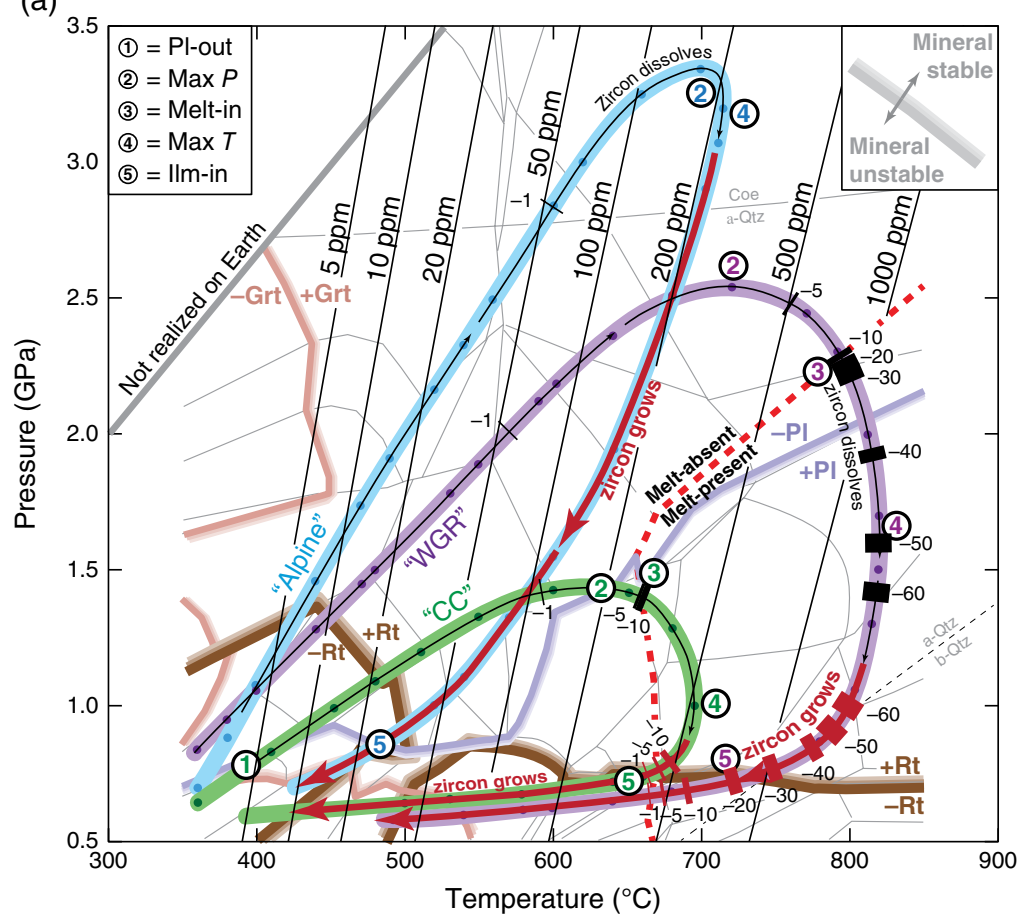

(b)

(c)

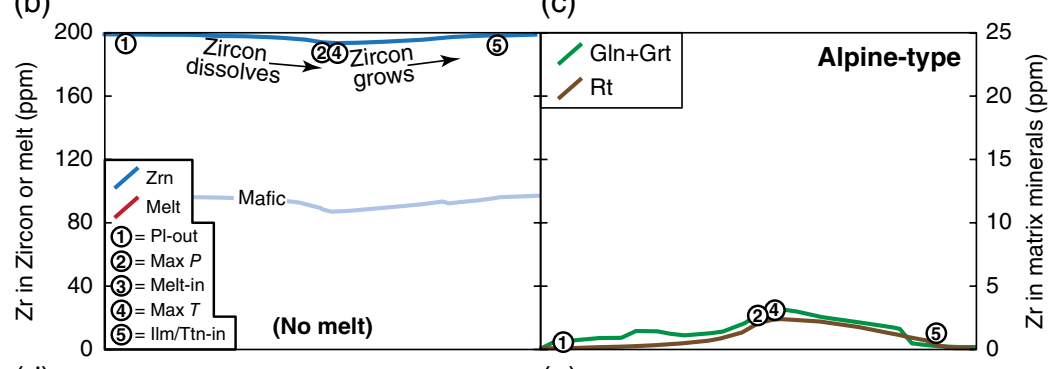

(d)
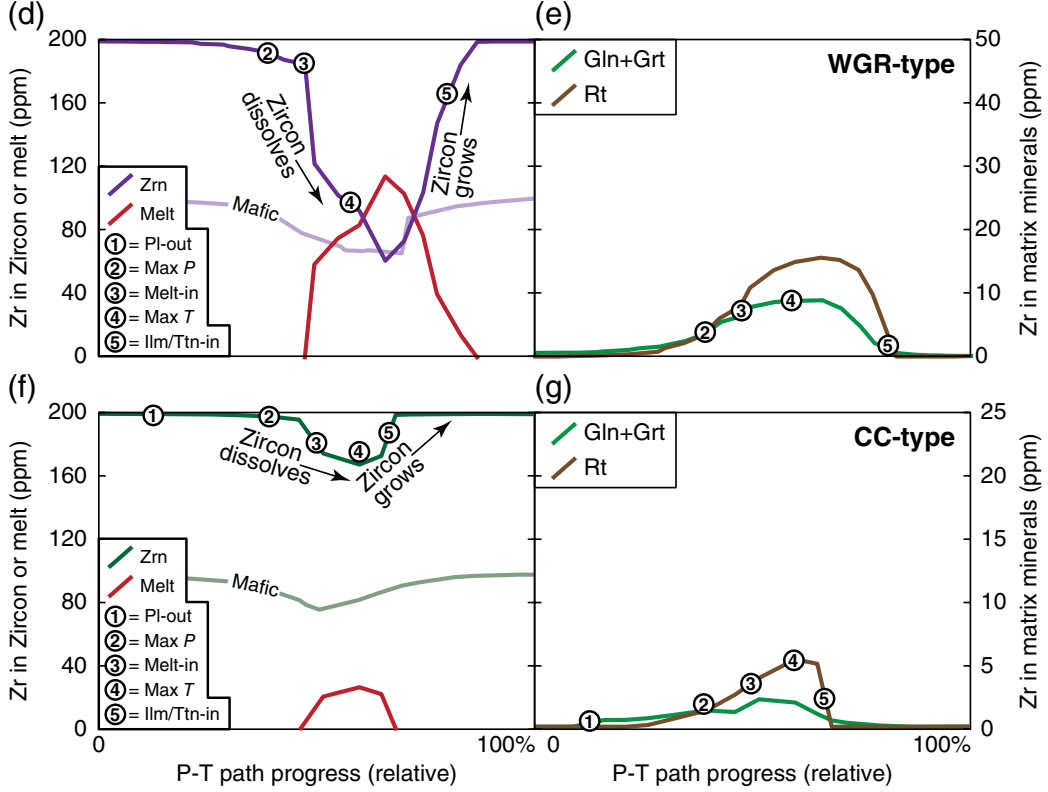

Figure 2.2 (a) Simplified petrogenetic grid for a metapelitic composition showing that the mode of zircon should decrease during prograde metamorphism and increase during retrograde metamorphism, especially if melting reactions are crossed. "Alpine," "WGR," and "CC" indicate representative P-T paths experienced by UHP rocks in the Alps, HP rocks in the Western Gneiss Region, and expected paths for models of continent-continent collision. (b-g) Main reservoirs of $\mathrm{Zr}$ along the P-T paths delineated in Figure 2.2a, showing decreases in the amount of zircon during prograde metamorphism and increases during retrograde metamorphism, as balanced against the $\mathrm{Zr}$ content of garnet, rutile, and melt. Zircon reservoir in mafic compositions shown for reference along the same P-T paths. Modified from Kohn et al. [2015]. 
and lacks overgrowths, whereas in leucosomes where melt has crystallized, or in melanosomes that have interacted with melts, zircon is euhedral and harbors large late-stage overgrowths (Fig. 2.1c) [Brouand et al., 1990; Kriegsman, 2001; Möller et al., 2003; Kriegsman and Álvarez-Valero, 2010]. The importance of melt in mobilizing $\mathrm{Zr}$ also explains why zircons from many sub-anatectic rocks host relatively thin, $\leq 1 \mu \mathrm{m}$ overgrowths, whereas zircons from anatectic rocks can host 10-30 $\mu \mathrm{m}$ thick overgrowths [e.g., Williams, 2001; Carson et al., 2002; Vorhies et al., 2013].

Qualitatively similar behavior for $\mathrm{Zr}$ mass balance is expected in metamorphosed mafic rocks, where hornblende and rutile should be especially abundant at higher temperatures and pressures. Very high solubility of $\mathrm{Zr}$ in rutile at high temperature dominates $\mathrm{Zr}$ uptake, but overall the amount of $\mathrm{Zr}$ taken up by major and minor minerals during prograde metamorphism is more limited than in rocks that undergo partial melting (Fig. 2.2b, d, and f) [Kohn et al., 2015]. At granulite-facies temperatures, sufficient $\mathrm{Zr}$ is dissolved in garnet, hornblende, and rutile that breakdown during cooling can drive zircon growth (Fig. 2.1b) [Fraser et al., 1997; Degeling et al., 2001; Ewing et al., 2013]. Indeed, precipitation of zircon during retrograde reequilibration of rutile has been documented in several high-temperature rocks [Meyer et al., 2011; Kooijman et al., 2012; Ewing et al., 2013; Pape et al., 2016]. This process requires either scavenging of $\mathrm{Si}$ from rutile (rutile does dissolve small amounts of $\mathrm{Si}$ ) or diffusion of Si from the rock matrix through rutile or along internal fast-diffusion pathways (see discussion in Taylor-Jones and Powell [2015] and Kohn et al. [2016]).

\subsubsection{Ostwald Ripening}

Ostwald ripening is a thermodynamically driven process that occurs because surface-free energies contribute less to the total free energy of a large crystal compared to a small crystal. This difference in free energy causes smaller crystals to dissolve and larger crystals to grow. In fact, dissolution rates of small crystals should accelerate as they become smaller. The theory was first proposed in the late 1800s [Ostwald, 1897], quantitatively established in the early 1960s [Lifshitz and Slyozov, 1961; Wagner, 1961], and modeled in metamorphic rocks at temperatures below melting [garnet; Miyazaki, 1996; see also Carlson, 1999] and during anatexis [zircon; Nemchin et al., 2001]. In general, the efficacy of small crystal dissolution depends on three key parameters: diffusion rate $(D)$ and concentration $(C)$ of the slowest-diffusing element required to stabilize the mineral, and the fraction of porosity in the rock $(\Phi)$. The work of Miyazaki [1996] is readily extrapolated to other systems because it explicitly accounts for variations in these parameters. Although Carlson [1999] showed that Miyazaki's conclusions regarding garnet were founded on unrealistically high values of $D, C$, and $\Phi$, the numerical results can nonetheless be applied to zircon to identify circumstances under which Ostwald ripening might occur. Here we consider two scenarios: zircon in a pre-anatectic, water-saturated rock, and in a rock containing $1-10 \%$ partial melt [see also Nemchin et al., 2001].

We calculated the efficacy of Ostwald ripening at temperatures of $600,650,700,750$, and $800^{\circ} \mathrm{C}$, with water present from 600 to $700^{\circ} \mathrm{C}$, and melt present from 700 to $800^{\circ} \mathrm{C}$. We assumed that the fraction of porosity in a water-saturated rock is uniformly $1 \times 10^{-4}$ [e.g., Carlson, 1999], and arbitrarily increases from $1 \%$ at the onset of melting at $700^{\circ} \mathrm{C}$ to $5 \%$ at $750^{\circ} \mathrm{C}$ and $10 \%$ at $800^{\circ} \mathrm{C}$. We assumed $\mathrm{Zr}$ kinetics (rather than $\mathrm{Si}$ ) limits ripening, so its $D$ and $C$ values must be estimated. For zircon solubility, we use experimental results in water [Wilke et al., 2012; Bernini et al., 2013] and in hydrous melt [Watson and Harrison, 1983; Boehnke et al., 2013]. Maximum Zr concentrations increase from $0.5 \mathrm{ppm}\left(600^{\circ} \mathrm{C}\right)$ to $2 \mathrm{ppm}$ $\left(700^{\circ} \mathrm{C}\right)$ in water, jumping to $50 \mathrm{ppm}\left(700^{\circ} \mathrm{C}\right)$ and $175 \mathrm{ppm}$ $\left(800^{\circ} \mathrm{C}\right)$ in melt. Diffusion rates were estimated from experiments for $\mathrm{Zr}$ diffusion in hydrous melts [Harrison and Watson, 1983; Koepke and Behrens, 2001; Baker et al., 2001] and for Ti diffusion in a nominally dry quartzite [Bromiley and Hiscock, 2016]. Expressing $D$ in $\mathrm{m}^{2} / \mathrm{s}$ and $C$ in $\mathrm{mol} / \mathrm{m}^{3}$, the product of $D \cdot C \cdot \Phi$ ranges from $4 \times 10^{-24}$ $\left(600^{\circ} \mathrm{C}\right)$ to $2 \times 10^{-22}\left(700^{\circ} \mathrm{C}\right)$ in a water-saturated rock, and ranges from $4 \times 10^{-19}$ to $1 \times 10^{-16}$ in an anatectic rock. These values are maximized because they assume diffusion through a stagnant fluid, whereas diffusion along grain boundaries may be slower. Conversely, the solubility of $\mathrm{Zr}$ increases in alkaline fluids [Ayers et al., 2012], so our calculations likely underestimate the efficacy of Ostwald ripening in more extreme fluid compositions.

Compared to Miyazaki's numerical calculations, Ostwald ripening for solute-poor water would not be expected prior to melting (Fig. 2.3). Only the smallest grains $(\leq 0.2 \mu \mathrm{m})$ at the highest temperature $\left(700^{\circ} \mathrm{C}\right)$ should dissolve in a water-saturated rock on timescales of 1-10 Ma. Melting, however, dramatically increases both porosity (from $1 \times 10^{-4}$ to $1 \times 10^{-2}$ ) and $\mathrm{Zr}$ concentration in fluid (from 2 to $50 \mathrm{ppm}$ ). These increases should drive small zircons to dissolve and form larger grains. For example, even at $700^{\circ} \mathrm{C}, 3 \mu \mathrm{m}, 1 \mu \mathrm{m}$, and $0.5 \mu \mathrm{m}$ radius zircons would dissolve on timescales of $1-10 \mathrm{Ma}, \sim 100 \mathrm{ka}$, and $\sim 10 \mathrm{ka}$, respectively. At $750-800^{\circ} \mathrm{C}$, Ostwald ripening of zircon appears inevitable (Fig. 2.3) [Nemchin et al., 2001], and explains anomalously large volumes of zircon overgrowth (ca. 70\%) in rocks with no direct evidence for pervasive melt transport, and whose maximum melt contents could dissolve only a much smaller fraction of zircon at any one time [Nemchin et al., 2001; Peck et al., 2010]. 
(a)

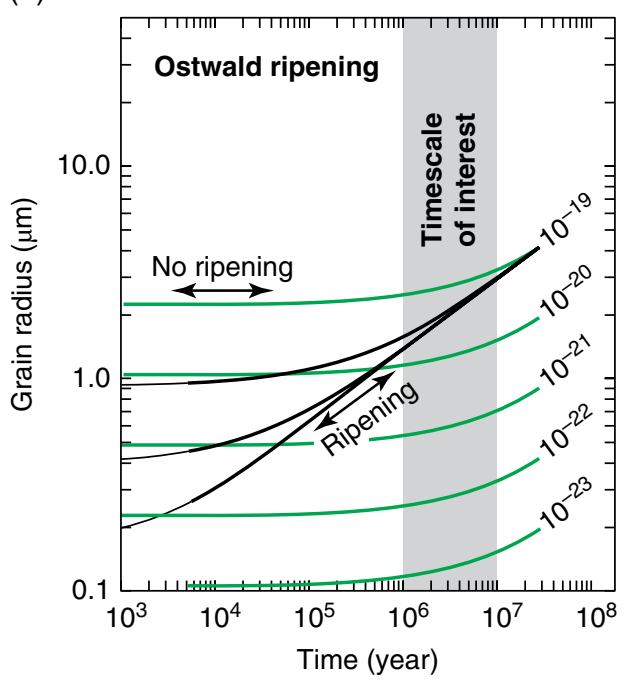

(b)

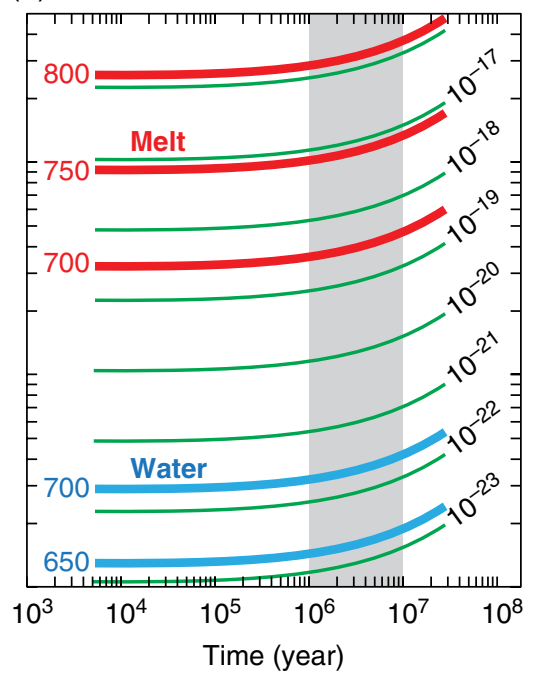

Figure 2.3 (a) Theoretical calculations scaled from Miyazaki [1996] of the efficacy of Ostwald ripening for zircon over different timescales, contoured for the product of $\mathrm{Zr}$ diffusivity $\left(D, \mathrm{~m}^{2} / \mathrm{s}\right), \mathrm{Zr}$ concentration $\left(C, \mathrm{~mol} / \mathrm{m}^{3}\right)$, and porosity $(\Phi$, dimensionless). This, flat, labeled lines imply no significant change to grain size; inclined lines imply Ostwald ripening. Thin, flat, labeled lines indicate the maximum grain size that would experience ripening on timescales of 1-10 Ma for a particular value of $D \cdot C \cdot \Phi$. For example, if $D \cdot C \cdot \Phi=10^{-19}$ (multiple converging lines), grains with initial radii of $\sim 2 \mu \mathrm{m}, 1 \mu \mathrm{m}, 0.4 \mu \mathrm{m}$, and $0.2 \mu \mathrm{m}$ would show slight Ostwald ripening on timescales of $\sim 1 \mathrm{Ma}, \sim 100 \mathrm{ka}, \sim 10 \mathrm{ka}$, and $\sim 1 \mathrm{ka}$, respectively, and would coarsen to grain sizes of $\sim 3 \mu \mathrm{m}$ on timescales of 1-10 Ma. Smaller grains could show coarsening with smaller values of $D \cdot C \cdot \Phi$. (b) Calculations of minimum grain size of zircon that would show Ostwald ripening in water-saturated rocks (lower thick lines) and anatectic rocks (upper thick lines). Ostwald ripening appears ineffective in water-saturated rocks of low solute content (only the smallest grains at the highest temperatures), but appears inevitable in anatectic rocks.

These results help interpret zircon growth in slates and greenschist-facies rocks. Calculations indicate that the diffusion rate and concentration of $\mathrm{Zr}$ within an intergranular medium appear to be far too low for significant crystalline zircon to dissolve during prograde metamorphism. Therefore, the compelling textural evidence for zircon growth at low metamorphic grades [Dempster et al., 2004; Rasmussen, 2005a; Hay and Dempster, 2009] suggests dissolution of either metamict zircon [Schmidt, 2006] or possibly zircon with high defect densities or unusual chemical composition rather than any thermodynamic instability of small zircon grains relative to larger ones. Because Ostwald ripening refers to a process driven solely by crystal size, presuming a fully crystalline structure and comparable defect densities, dissolution-reprecipitation of metamict zones probably best explains low-temperature zircon textures (Fig. 2.1a). Evidence for moderate-grade growth of zircon [e.g., Dempster et al., 2008; Gauthiez-Putallaz et al., 2016] does imply that zircon solubility or reactivity must be higher in some rocks, but we do not know whether differences among rocks reflect differences in survival of metamict grains to higher temperatures (although see Pidgeon [2014]) versus other controls (e.g., fluid composition) that may affect zirconium solubility.

\subsection{ANALYTICAL STRATEGIES}

We briefly discuss analytical methods to provide context for later examples. Classically, zircons have been dated using isotope-dilution, thermal ionization mass spectrometry (ID-TIMS). This method is still unsurpassed for analytical precision and accuracy, with uncertainties now routinely $\leq 0.1 \%$. Research on metamorphic zircon has almost entirely abandoned this approach, however, not only because inherited pre-metamorphic cores are nearly ubiquitous, causing discordant dates, but also because zircons in metamorphic rocks inevitably contain multiple growth domains of different ages and compositions (Fig. 2.4a). As petrologists have come to appreciate the varying P-T conditions and mechanisms through which zircon forms along both prograde and retrograde P-T paths (Fig. 2.1), so too have they abandoned the notion that a single bulk zircon age carries much petrologic significance: it could reflect early diagenesis, peak (or near-peak) metamorphic conditions, some retrograde stage (Fig. 2.1), or, more likely, some combination of all these processes. That is, although ID-TIMS can precisely define an age, analysis inevitably mixes different domains of different origins and unknown proportions, so the age cannot be uniquely 
(a)

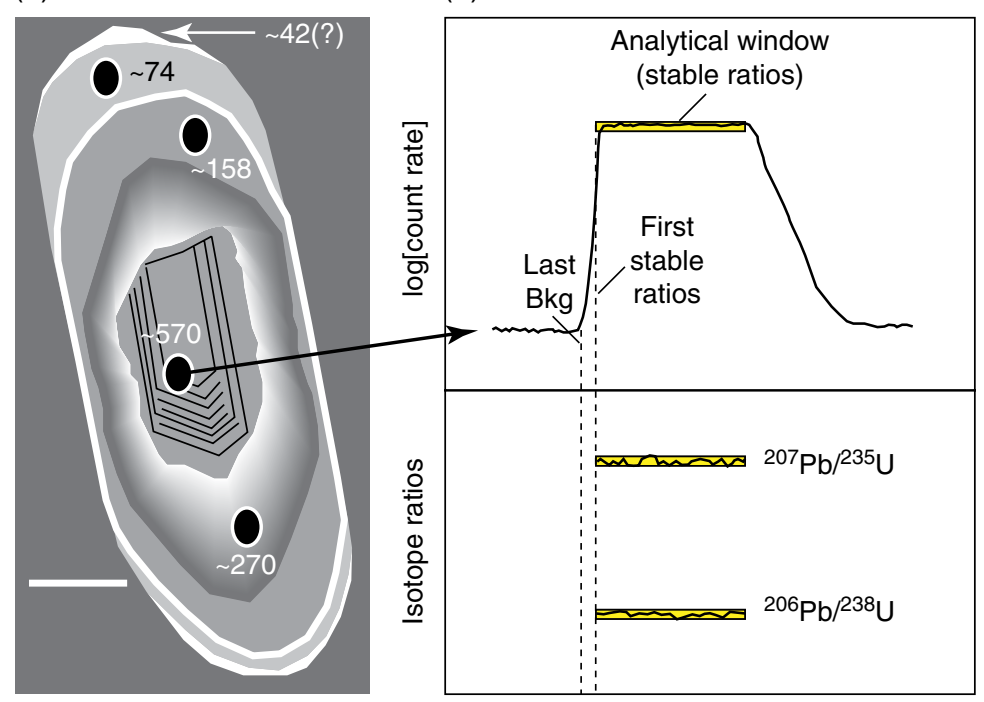

(c)

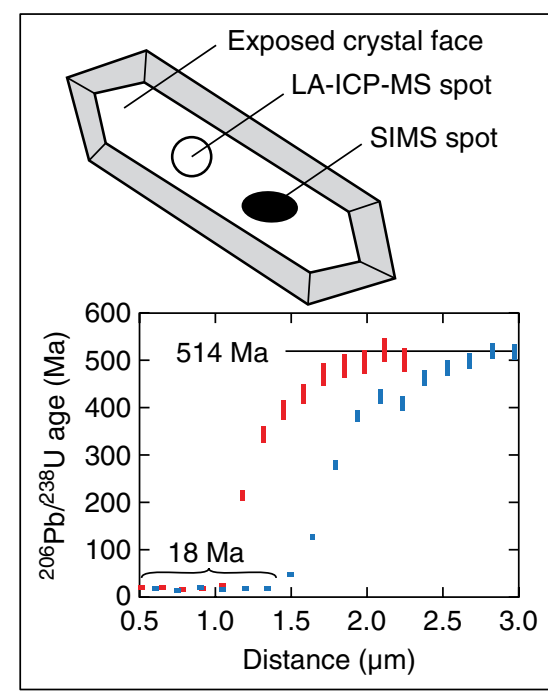

Figure 2.4 (a) Sketch of a CL image of zircon from Rhodope, Greece, showing multiple zones with different ages. Spots are locations of SIMS analyses; numbers are preferred ages in Ma for different zones. Modified from Liati et al. [2016]. (b) Schematic of a typical data stream, including raw count rate and isotope ratios. Initial data are not reliable until sputtering or ablation stabilizes. (c) Schematic of depth profiling method: crystal surface is exposed in a flat mount and progressively sputtered (SIMS) or ablated (LA-ICP-MS), collecting age information with depth. Depth profiling data using single-shot method on two Himalayan zircons reveal ca. 18Ma, 1-1.5 $\mu \mathrm{m}$ thick rims that overgrew ca. $514 \mathrm{Ma}$ cores. Outermost analyses had high common Pb and were not plotted. Modified from Cottle et al. [2009].

linked to any point on the P-T path. Consequently, research has largely shifted to microanalysis of individual domains, linking each domain to metamorphic reactions or P-T conditions via inclusion assemblages or geochemistry [this work; Rubatto, 2017]. That information is then used to define the P-T-t evolution.

Standard analytical approaches in metamorphic zircon geochronology now include imaging using cathodoluminescence (CL) and back-scattered electrons (BSE) to identify different domains (Fig. 2.4a), followed by in situ spot analysis to measure trace elements and ages via secondary-ion mass spectrometry (SIMS or ion microprobe) or laser ablation, inductively coupled plasma, mass spectrometry (LA-ICP-MS, both single-collector and multi-collector; Fig. 2.4b). As one example (among thousands), CL imaging of zircons from the Rhodope complex, Greece, reveals five different domains: two inner domains (ca. 570 and $270 \mathrm{Ma}$ ) of inherited igneous origin, and overgrowths of progressively younger ages, interpreted to reflect different stages of (poly)metamorphism [Liati et al., 2016].

For LA-ICP-MS analysis, significant time-dependent fractionation of inter-element ratios can occur during an analysis, which must be corrected, and U-Pb ages may be slightly but reproducibly different from ID-TIMS ages [e.g., Black et al., 2004; Allen and Campbell, 2012]. Annealing zircons prior to analysis precludes fission-track or U-Th/He dating, but substantially reduces downhole fractionation (Fig. 2.4b), and improves comparisons with ID-TIMS ages [Allen and Campbell, 2012]. Typical spot sizes range from 20 to $35 \mu \mathrm{m}$. Extraordinary spatial resolution is achieved by mounting grains without polishing so that natural surfaces are exposed, followed by depth profiling with either SIMS or LA-ICP-MS (Fig. 2.4c) [e.g., Carson et al., 2002; Cottle et al., 2009]. This method sacrifices count rate (precision) for sub-micron scale resolution of ages and chemistry, and is particularly helpful when rims are thin $(\leq 1 \mu \mathrm{m})$ and overgrow cores of extremely different age [e.g., Carson et al., 2002; Breeding et al., 2004; Cottle et al., 2009].

Careful observation of the textural context of metamorphic minerals, linked to their major, minor, or trace element chemistry, is integral to the interpretation of metamorphic histories. Therefore, the textural context of metamorphic zircon is fundamental to understanding its growth origin because textures allow more confident links between zircon ages and reactions for which P-T information can be extracted. The improved ability to measure isotopes and trace element compositions in situ (described above), especially the use of "out of mount" standards and sample holders that can take thin sections (LA-ICP-MS), increases impetus to retain textural contexts rather than extracting zircon through crushing rocks. For example, Möller et al. [2003] used in 
situ analysis of zircon in thin sections to place age constraints on three stages of metamorphism in the Rogaland area of Norway (Fig. 2.5a and b). In that study, early zircon rims intergrown with magnetite date the "M2" metamorphic event, while outer growth zones that are in turn rimmed by retrograde garnet place maximum age limits on the "M3" retrograde event. Had

(a)

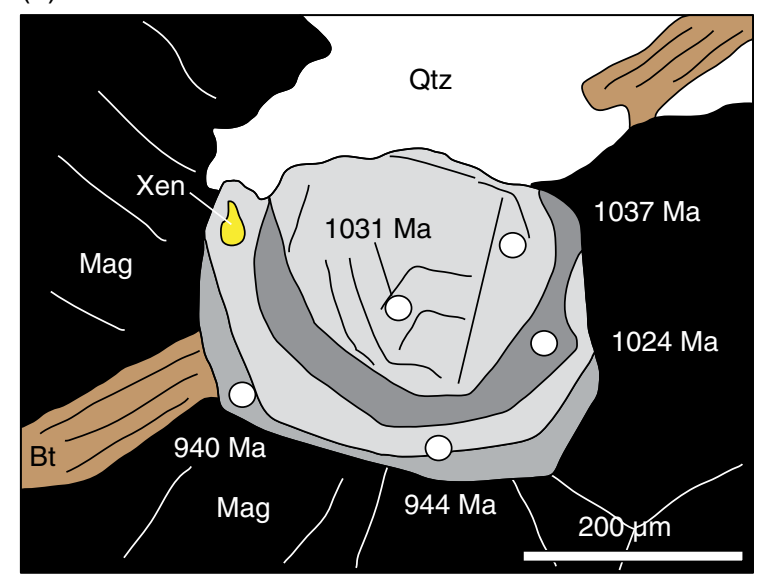

(b)

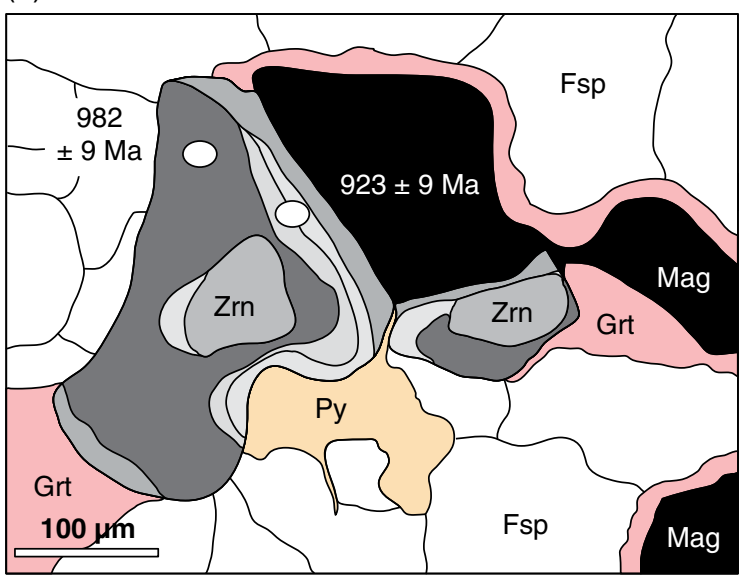

(c)

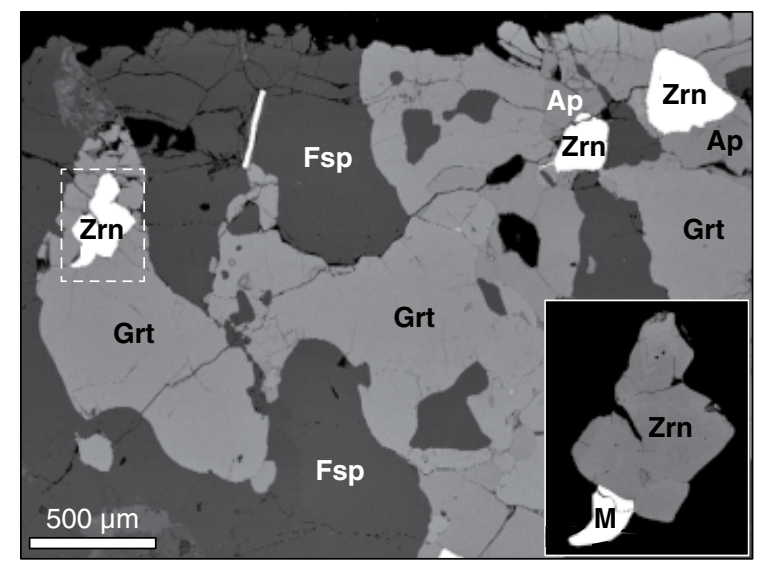

zircon been separated from the rock, such key textures would have been lost. In migmatites, due to the potential for entrainment and transport of minerals within melt, a textural approach may also better underpin isotopic and trace element geochemical interpretations. For example, zircon with monazite overgrowths is included within garnet and apatite intergrowths in a late, crosscutting melt vein (Brattstrand Bluffs, east Antarctica; Kelly [unpublished data]; Fig. 2.5c). In conjunction with trace elements, which display gross disequilibrium partitioning between zircon and garnet, these textures suggest that the zircon was likely entrained from the melt source and does not date crystallization of the late-stage partial melt. Again, textures are key for interpreting zircon ages and chemistry.

\subsection{INCLUSION ASSEMBLAGES}

Minerals and mineral assemblages may be restricted to certain regions of P-T space (Fig. 2.6), for example, coesite and diamond alone define UHP conditions $(P>\sim 2.5 \mathrm{GPa})$, whereas hornblende plus plagioclase are restricted to the amphibolite and (lower) granulite facies (roughly $\leq \sim 1.0 \mathrm{GPa}$ and $T>500^{\circ} \mathrm{C}$ ). The occurrence of distinctive minerals or assemblages as inclusions in zircon can therefore define the P-T conditions of zircon formation. Linking together different zircon domains with different inclusions helps elucidate the P-T path. Probably the best known examples involve UHP inclusions of coesite or diamond in zircon, which have been

Figure 2.5 Sketches of textural relationships between zircon and other minerals, demonstrating the utility of retaining textural context for interpreting zircon ages and chemistry. Circles and ellipses represent locations of SIMS U-Pb analyses. (a and b) Zircon textures from high-temperature gneisses, Rogaland, Norway. Modified from Möller et al. [2003]. (a) Zircon (gray tones) partially enclosed in titaniferous magnetite. The outer zircon rim is $\mathrm{Y}$ - and P-enriched and contains a xenotime inclusion. (b) Zircon (labeled gray tones) intergrown with magnetite, with a retrograde garnet corona (M3) that developed on magnetite and encloses zircon. The zircon shows an inherited core and multiple rim generations formed through growth and/or recrystallization. Inherited cores (ca. 1050-1020Ma) are rimmed by multiple zircon generations. Zircon mantles give estimates for M1 (ca. $1015 \mathrm{Ma}$, locally partially reset). Zircon rims are intergrown with or occur inside M2 minerals (ca. 940$930 \mathrm{Ma}$ ), while those rimmed by M3 minerals give ages down to ca. $908 \mathrm{Ma}$. (c) Zircon, locally rimmed by monazite and included in intergrowths of garnet and apatite, from a late-crystallized partial melt. Trace element compositions suggest zircon growth in a more HREE-enriched melt compared to the HREE-depleted garnet [Kelly, unpublished data]. 


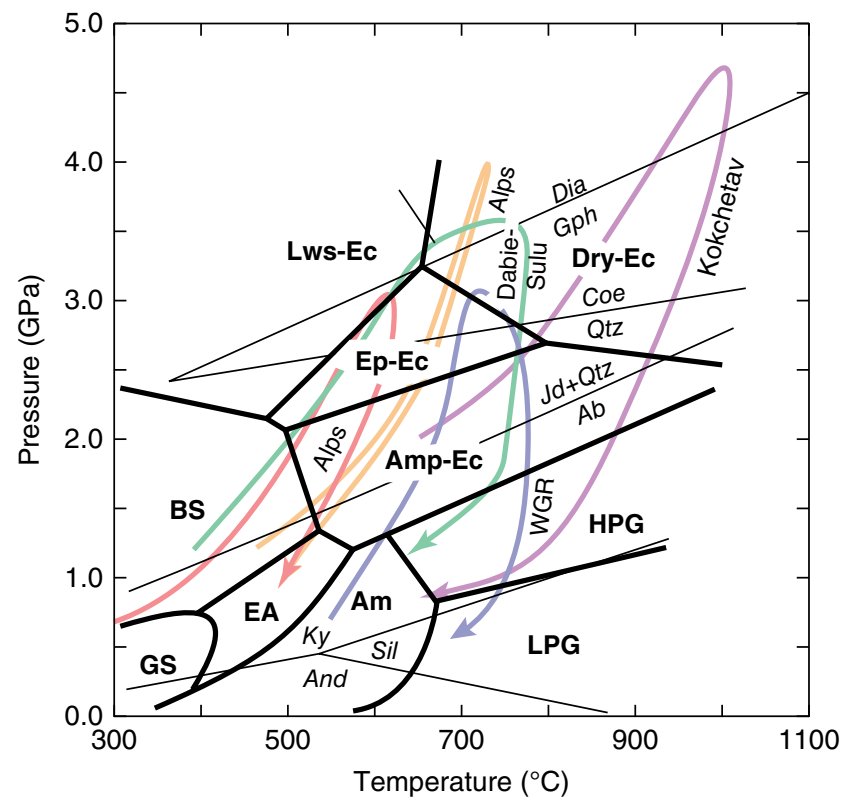

Figure 2.6 Simplified P-T diagram delineating main metamorphic facies and key mineral reactions. Zircons that grow in a specific facies or mineral stability field may be expected to harbor inclusions diagnostic of that facies or field. P-T paths of several UHP terranes illustrate how different paths cross different mineral stability fields. Modified from Rubatto and Hermann [2003a] and Gauthiez-Putallaz et al. [2016]. For facies and reaction boundaries, see sources in Liou et al. [1998] and Kohn [2014]. Mineral abbreviations: Ab, albite; And, andalusite; Coe, coesite; Dia, diamond; Gph, graphite; Jd, jadeite; Ky, kyanite; Qtz, quartz; and Sil, sillimanite. Facies abbreviations: Am, amphibolite; Amp-Ec, amphibole eclogite; BS, blueschist; Dry-Ec, dry eclogite; EA, epidote amphibolite; Ep-Ec, epidote eclogite; GS, greenschist; HPG, high-pressure granulite; LPG, low-pressure granulite; and Lws-Ec, lawsonite eclogite.

observed in numerous orogens worldwide, for example, Kokchetav [Sobolev and Shatsky, 1990], Indonesia [Parkinson and Katayama, 1999], Erzgebirge [Nasdala and Massonne, 2000; Massonne, 2001], Caledonides [Carswell et al., 2003; McClelland et al., 2006; Smith and Godard, 2013], Himalaya [Kaneko et al., 2003], western Alps [Schertl and Schreyer, 1996], Dabie-Sulu [Tabata et al., 1998; Liu et al., 2007], and so on. Dating the domains that host these inclusions using SIMS or LAICP-MS provides a minimum estimate of the time at which the rock first entered the stability field of the inclusion assemblage and helps define rates of subduction or exhumation. Actually, finding such diagnostic inclusions may require extraordinary efforts, however. For example, McClelland et al. [2006] report investigating over 1700 zircon grains that had been pre-selected to contain inclusions, and finding only 6 that contained coesite, that is, a $\sim 1 / 300$ success rate.

\subsection{WHAT DOES METAMORPHIC ZIRCON CHEMISTRY TELL US?}

While in situ textural relationships between metamorphic zircon and major or other accessory minerals improve petrogenetic and chronologic interpretations, the chemistry of zircon provides an additional, complementary view of the origin of a zircon generation. The minor and trace element composition of zircon will reflect the integrated effects of element availability (bulk rock, or in many cases a smaller reaction environment), partitioning between zircon and other phases (including melt), and competition with minerals in which the element of interest is a major structural constituent (e.g., Th in monazite). Therefore, measurement of these elements, coupled with an understanding of how they are distributed within and between minerals, allows one to link growth of zircon to metamorphic processes.

\subsubsection{Crystal-Chemical Controls on Trace Element Uptake}

The crystal structure of zircon allows substitution of a wide variety of minor and trace elements of petrologic importance (e.g., Hf, Ti, P, lanthanides, Y, Sc, and Nb). Due to the larger radius of the crystallographic sites for $\mathrm{Zr}^{4+}$ versus $\mathrm{Si}^{4+}[\sim 0.84$ and $0.26 \AA$, respectively; Finch and Hanchar, 2003], most moderate- to high-radius trace elements substitute for $\mathrm{Zr}^{4+}$. Key simple substitutions of interest to dating metamorphism include $\mathrm{Hf}^{4+}, \mathrm{U}^{4+}$ and $\mathrm{Th}^{4+}$ for $\mathrm{Zr}^{4+}$, and $\mathrm{Ti}^{4+}$ for $\mathrm{Si}^{4+}$ [Thomas et al., 2010], while incorporation of trivalent cations such as the rare earth elements $(\mathrm{REE}=$ lanthanides plus $\mathrm{Y}$ and $\mathrm{Sc})$ are explained by coupled substitutions including $\mathrm{REE}^{3+}+\mathrm{P}^{5+}=\mathrm{Zr}^{4+}+$ $\mathrm{Si}^{4+}$ and $\mathrm{REE}^{3+}+\left(\mathrm{H}^{+}, \mathrm{Li}^{+}\right)=\mathrm{Zr}^{4+}$ where the monovalent cation occupies an interstitial position [Frondel, 1953; Es'kova, 1959; Speer, 1982; Caruba and Iacconi, 1983; Hanchar et al., 2001; Hinton et al., 2003; Trail et al., 2011, 2016; de Hoog et al., 2014].

\subsubsection{Th/U Ratios}

The minor-to-trace elements most commonly used to interpret zircon petrogenesis are $\mathrm{Th}$ and $\mathrm{U}$ (or $\mathrm{Th} / \mathrm{U}$ ), most probably because element concentrations are directly calculated from isotope analysis for geochronology. In igneous zircon, total $\mathrm{Th}+\mathrm{U}$ will reflect crystal-melt partitioning and magma composition, leading to characteristic variations in zircon $\mathrm{Th} / \mathrm{U}$. For example, for typical crustal rocks, zircon $\mathrm{Th} / \mathrm{U}$ is $\sim 0.5-0.8$, with a possible dependence on magma temperature during zircon crystallization [e.g., mafic vs. granitic magmas; Wang et al., 2011]. Other factors that influence $\mathrm{Th} / \mathrm{U}$ include crystallization and separation of early magmatic phases prior to 
zircon growth, more extreme fractionation products [e.g., enrichment of $\mathrm{U}$ in late stage granites or pegmatites; Kelly et al., 2008; Appleby et al., 2010], and importantly, growth rate and equilibrium versus disequilibrium crystal growth [Wang et al., 2011; Kirkland et al., 2015].

In contrast to the high $(>0.5) \mathrm{Th} / \mathrm{U}$ seen in igneous zircon, metamorphic zircon is commonly characterized by low $(<0.1) \mathrm{Th} / \mathrm{U}$ values [Williams et al., 1996; Williams, 2001; Rubatto, 2002]. This cutoff has been used almost ubiquitously to discriminate between the two zircon "types" for interpreting ages from metamorphic and sedimentary rocks. The low Th/U may reflect scavenging of Th by monazite (common in metamorphic rocks) or higher mobility of $\mathrm{U}$ over $\mathrm{Th}$ in metamorphic fluids. While both interpretations may be valid, the Th/U criterion is somewhat simplistic. For example, metamorphic zircon rims or domains may not always grow in equilibrium with the entire matrix but may instead adopt a composition from pre-existing zircon [e.g., Pidgeon, 1992; Hoskin and Black, 2000; Möller et al., 2002, 2003; Kelly et al., 2004]. The $\mathrm{Th} / \mathrm{U}$ of zircon grown in the presence of partial melt may well approach that of igneous zircon [due to breakdown of monazite during anatexis; Montel, 1993; Kelsey and Powell, 2011], unless growth occurred from late-crystallized fractionated (high-U) melts. Fluid mediated growth can also cause high $\mathrm{Th} / \mathrm{U}$, such as in Labwor Hills granulites, where leaching of Th from local monazite led to typical $\mathrm{Th} / \mathrm{U}$ in metamorphic zircon $>5$, and as high as 46 [Möller and Kennedy, 2006]. These observations, taken together, present a more complicated but comprehensive picture of metamorphic $\mathrm{Th} / \mathrm{U}$ behavior. Comparable with magmatic zircon, $\mathrm{Th} / \mathrm{U}$ will reflect the local reaction environment, formation mechanisms, growth rates, and equilibrium versus disequilibrium processes. Therefore, $\mathrm{Th} / \mathrm{U}$ should be used with caution, and not isolated from other petrologic information.

\subsubsection{Titanium Thermometry}

The temperature dependence of Ti uptake by zircon has led to the increased use of Ti-in-zircon thermometry to constrain the temperatures of zircon formation. On the basis of equilibration of zircon with rutile and quartz $\left[\mathrm{a}_{\mathrm{SiO}_{2}}\right.$ and $\mathrm{a}_{\mathrm{TiO}_{2}}=1$; Watson et al., 2006], the thermometer has been re-formulated for the presence of other Ti-bearing phases (e.g., ilmenite, where $\mathrm{a}_{\mathrm{TiO}_{2}}<1$ ) or to estimate uncertainties where the Ti-saturating phase is unknown (e.g., magmas) or where quartz is absent $\left[\mathrm{a}_{\mathrm{Si}_{2}}<1\right.$; Ferry and Watson, 2007]. In rocks that contain quartz and either muscovite, biotite, or hornblende, $\mathrm{a}_{\mathrm{TiO}_{2}}$ may be estimated independently from calibrated equilibria [Chambers and Kohn, 2012], as can $\mathrm{a}_{\mathrm{SiO}_{2}}$ in quartz-absent, rutile-bearing rocks. The low diffusivity of Ti in zircon [Cherniak and Watson, 2007] indicates that the thermobarometer should record the temperature of growth and not post-growth re-equilibration (up or down temperature). However, care should be taken due to the potential impact of disequilibrium growth [Fu et al., 2008] and analytical issues. These include elevated $\mathrm{Ti}$ contents at grain boundaries introduced during sample preparation [Hiess et al., 2008] or from detrital grain coatings, X-ray fluorescence from Ti-rich boundary phases, or accidental analysis of Ti-rich micro-inclusions.

\subsubsection{Rare Earth Elements}

The REE are particularly useful trace elements for tracking petrogenetic processes. The "lathanide contraction" (decreasing ionic radius with increasing atomic number from $\mathrm{La}=1.16 \AA$ to $\mathrm{Lu}=0.98 \AA \AA$ ) leads to increasing affinity of heavy REE (HREE: Gd-Lu) over the light REE (LREE: La-Eu) in the $\mathrm{Zr}^{4+}$ site, and characteristically steep positive slopes on chondrite-normalized plots of element concentration (Fig. 2.7a). Deviations from the typically smooth increase in REE concentration from $\mathrm{La}$ to $\mathrm{Lu}$ include common enrichment in $\mathrm{Ce}$ and depletion in $\mathrm{Eu}$, which have been linked to redox state [Hinton and Upton, 1991; Ballard et al., 2002; Pettke et al., 2005; Trail et al., 2012]. The magnitude of a "positive" Ce anomaly (Ce*, or excess compared to expectations from neighboring $\mathrm{La}$ and $\mathrm{Pr}$ ) is inferred to reflect abundance of the more zircon-compatible, oxidized, $\mathrm{Ce}^{4+}$ relative to $\mathrm{Ce}^{3+}$. Similarly, the magnitude of a "negative" Eu anomaly (Eu*, or depletion compared to expectations from neighboring $\mathrm{Sm}$ and $\mathrm{Gd}$ ) is inferred to reflect abundance of the less zircon-compatible, reduced, $\mathrm{Eu}^{2+}$ relative to $\mathrm{Eu}^{3+}$.

During metamorphism, feldspar mass balance exerts the strongest influence on $\mathrm{Eu}^{*}$ because plagioclase and $\mathrm{K}$-feldspar strongly partition $\mathrm{Eu}^{2+}$ relative to the matrix. Because divalent $\mathrm{Eu}$ is not taken up by zircon, loss of $\mathrm{Eu}^{2+}$ alone to feldspar should not affect zircon REE patterns. The reason feldspar growth affects $\mathrm{Eu}^{3+}$ is because the redox state of trace $\mathrm{Eu}$, as reflected by its $\mathrm{Eu}^{2+}-\mathrm{Eu}^{3+}$ ratio, must be dictated by the redox state of the rock, which will be defined by more abundant, redox-sensitive elements such as Fe. That is, the $\mathrm{Eu}^{2+}-\mathrm{Eu}^{3+}$ ratio in the reactive rock is fixed by more abundant heterovalent ions and should not depend on the growth of any mineral, including feldspar. Thus, as $\mathrm{Eu}^{2+}$ is removed from the reactive rock through progressive feldspar growth and sequestration of $\mathrm{Eu}^{2+}$ in crystal interiors, some $\mathrm{Eu}^{3+}$ in the matrix must convert to $\mathrm{Eu}^{2+}$. Reducing a trace amount of $\mathrm{Eu}^{3+}$ to $\mathrm{Eu}^{2+}$ could be balanced by commensurate oxidation of a trace amount of $\mathrm{Fe}^{2+}$. This process progressively removes $\mathrm{Eu}^{3+}$ from the reactive rock, leading to an increasingly negative $\mathrm{Eu}^{3+}$ anomaly in later-grown minerals [Kohn, 2016]. Melting and melt extraction in migmatites might 
(a)

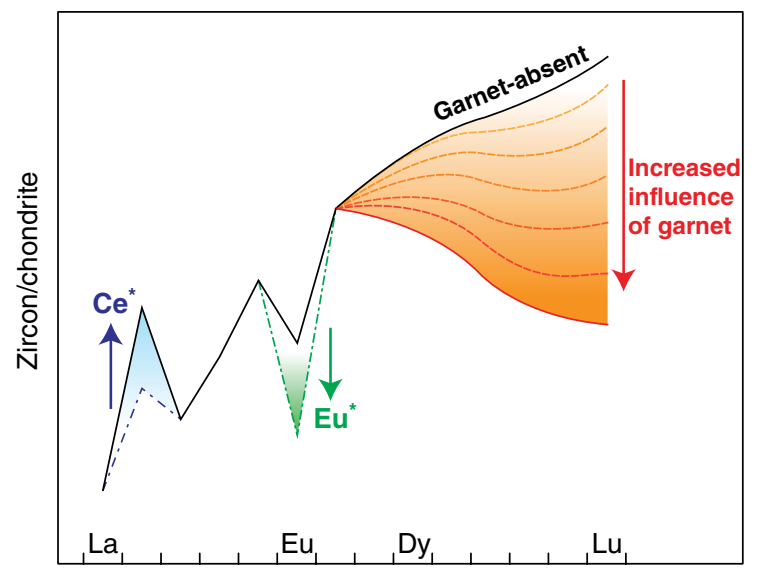

(c)

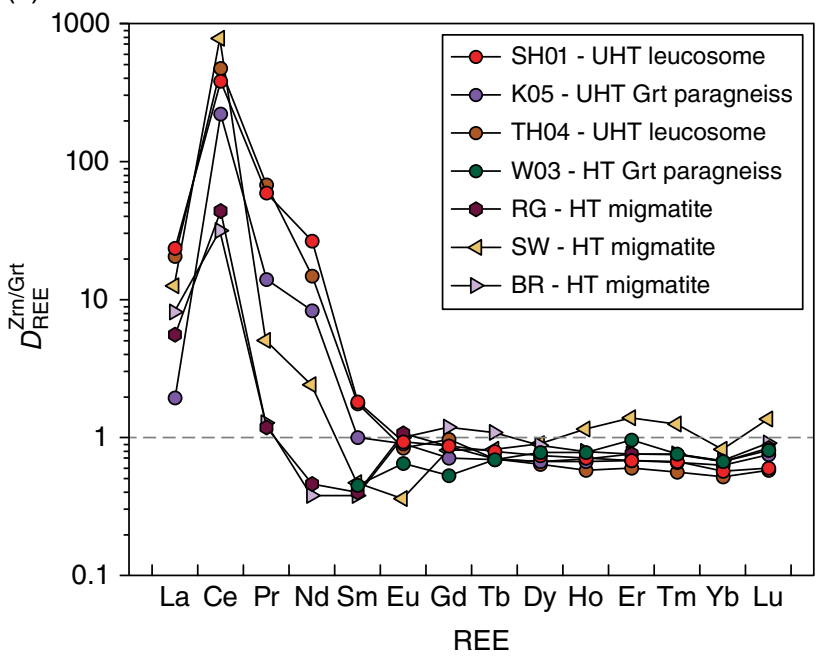

(b)

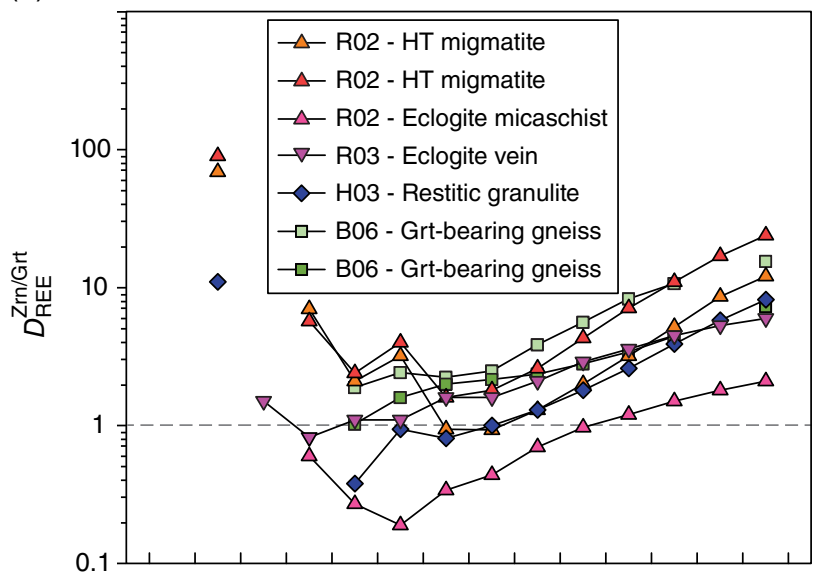

(d)

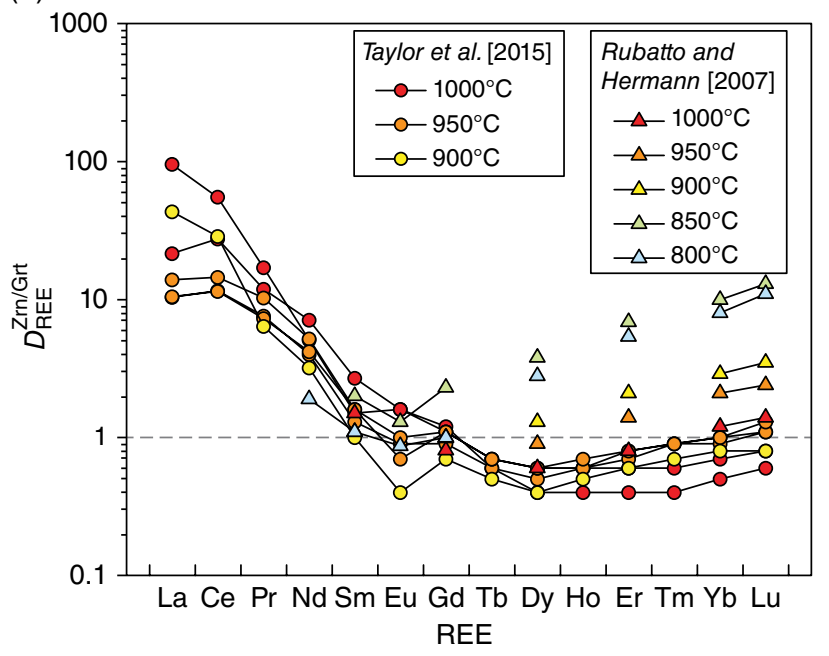

Figure 2.7 (a) Schematic diagram illustrating general trends of chondrite-normalized, absolute REE concentrations in metamorphic zircon. Ce* refers to the positive Ce anomaly, and Eu* refers to the negative Eu anomaly. See text for full explanation. (b) Empirical studies of high-temperature and high-pressure metamorphic rocks where $D_{\mathrm{HREE}}^{\mathrm{Zrn} / \mathrm{Grt}}$ values appear to increase with increasing atomic number. R02: Rubatto [2002]; R03: Rubatto and Hermann [2003b]; H03: Hermann and Rubatto [2003]; B06: Buick et al. [2006]. (c) Empirical studies of zircon in high- and ultrahigh-temperature metamorphic rocks where $D_{\mathrm{HREE}}^{\mathrm{Zrn} / \mathrm{Grt}}$ values appear to show essentially no dependence on atomic number. SH01: Harley et al. [2001]; K05: Kelly and Harley [2005]; TH04: Hokada and Harley [2004]; W03: Whitehouse and Platt [2003]; RG: Rauer Group, Kelly [unpublished data]; SW: Stillwell Hills, Kelly [unpublished data]; BR: Brattstrand Bluffs, Kelly [unpublished data]. Data cover a range of peak temperature conditions and metasedimentary rock (therefore partial melt) compositions. (d) Experimentally derived $D_{\mathrm{REE}}^{\mathrm{Zrn} / \mathrm{Grt}}$. The experimental data of Rubatto and Hermann [2007] show increasing $D_{\mathrm{HREE}}^{\mathrm{Zrn} / \mathrm{Grt}}$ with increasing atomic number and imply a decreasing preference for the HREE in zircon with increasing temperatures (garnet compositions also vary from $X_{\mathrm{Grs}}=0.22$ at $800^{\circ} \mathrm{C}$ to $X_{\mathrm{Grs}}=0.08$ at $1000^{\circ} \mathrm{C}$ ). Experimental data of Taylor et al. [2015] show relatively flat $D_{\mathrm{HREE}}^{\mathrm{Zrn} / \mathrm{Grt}}$ and no temperature dependence; garnet is Ca-absent.

also cause extremely negative $\mathrm{Eu}^{*}$ in zircon if $\mathrm{Eu}^{2+}$ is progressively lost to fractionally crystallizing feldspar or to melt that leaves the rock [e.g., Harley and Nandakumar, 2014]. In fact, progressive growth of zircon through continuous melting and melt loss may possibly be tracked by increasingly negative $\mathrm{Eu}^{*}$. In contrast, breakdown of plagioclase as rocks enter the eclogite facies will liberate all $\mathrm{Eu}^{2+}$, much of which will convert to $\mathrm{Eu}^{3+}$, erasing the $\mathrm{Eu}$ anomaly in the reactive rock. This is why eclogitefacies zircon commonly has only a slightly negative $\mathrm{Eu}^{*}$ [Rubatto, 2002; Rubatto and Hermann, 2003b; Whitehouse and Platt, 2003]. 
Deviations from typical REE patterns occur when zircon grows in equilibrium with or after growth of a competitor phase. For example, prior or concurrent growth of monazite may deplete LREE in the reactive rock and produce even steeper REE patterns in zircon. However, the petrologically important mineral garnet imparts the most commonly reported REE perturbations. Garnet has REE concentrations that are broadly similar to zircon [Bea, 1996], but can develop much higher modal abundances and consequently can dominate the whole-rock HREE budget. Garnet growth depletes the reactive rock in HREE, so any concurrent or subsequent zircon records a flat- or even negative-HREE slope on a chondrite-normalized diagram (Fig. 2.7a).

The role that garnet plays in understanding the P-T history of a metamorphic rock means that a key area of ongoing research and debate focuses on the relative timing of zircon and garnet growth, especially establishing equilibrium partitioning coefficients for the REE $\left(D_{\mathrm{REE}}^{\mathrm{Zrn} / \mathrm{Grt}}\right)$. Early empirical studies yielded contrasting estimates. Rubatto [2002] proposed that $D_{\mathrm{REE}}^{\mathrm{Zrn} / \mathrm{Grt}}$ in granulite-facies migmatite increases with increasing atomic number from $D_{\mathrm{Gd}}^{\mathrm{Zrn} / \mathrm{Grt}} \approx 1$ to $D_{\mathrm{Lu}}^{\mathrm{Zrn} / \mathrm{Grt}} \approx 10$ (Fig. $2.7 \mathrm{~b}$ ). However, results from zircon and garnet in a UHT leucosome [Harley et al., 2001] and a HT garnet-bearing paragneiss [Whitehouse and Platt, 2003] suggest $D_{\mathrm{REE}}^{\mathrm{Zn} / \mathrm{Grt}} \approx 0.8-1$ across all middle and heavy REE (Fig. 2.7c). Additional studies have confirmed both observations (Fig. 2.7b-d), with suggestions that steep-HREE patterns for zircon in garnet-bearing rocks $\left(D_{\mathrm{HREE}}^{\mathrm{Zrn} / \mathrm{Grt}} \approx 1-10\right)$ might reflect zircon growth within equilibrium volumes that do not include garnet, or flat-HREE patterns $\left(D_{\mathrm{HREE}}^{\mathrm{Zrn} / \mathrm{Grt}} \approx 0.8-1\right)$ reflecting growth after garnet has already depleted the reaction environment of HREE.

In the first experimental study on zircon-garnet REE partitioning in Ca-bearing hydrous melt (at $2.0 \mathrm{GPa}$, $\left.800-1000^{\circ} \mathrm{C}\right)$, Rubatto and Hermann [2007] reproduced the earlier results of Rubatto [2002], but reported a systematic shift in partitioning values with increasing temperature where $D_{\mathrm{HREE}}^{\mathrm{Zrn} / \mathrm{Grt}}$ values at $1000^{\circ} \mathrm{C}$ were similar to earlier reports of Harley et al. [2001] (Fig. 2.7d). However, more recent experimental data for zircon and garnet grown in a Ca-absent melt (equivalent to that grown through partial melting of a pelitic rock composition [Taylor et al., 2015]) showed no such temperature dependence and confirmed interpretations for $D_{\mathrm{HREE}}^{\mathrm{Zrn} / \mathrm{Grt}} \approx 0.8-1$ (Fig. 2.7d). The differences in observations (and interpretations) for zircon-garnet REE partitioning may reflect our weak understanding of how REE substitutions in garnet and zircon depend on P-T conditions. At least two different substitution mechanisms have been proposed for zircon (see above), and possible substitution mechanisms for garnet include ${ }^{\mathrm{VIII}} \mathrm{REE}^{3+}+{ }^{\mathrm{VIII}} \mathrm{Na}^{+}=2^{\mathrm{VIII}} \mathrm{Mg}^{2+}$ or ${ }^{\mathrm{VI}} \mathrm{Mg}^{2+}$ $+{ }^{\mathrm{VIII}} \mathrm{REE}^{3+}={ }^{\mathrm{VIII}} \mathrm{Mg}^{2+}+{ }^{\mathrm{VI}} \mathrm{Al}^{3+}$. Any of these substitutions could have a strong P-T dependency, influencing equilibrium
$D_{\text {REE }}$ values. The issue will remain unresolved until zircon and garnet crystal chemistries are better understood.

\subsubsection{Effects of Reheating}

Localized nano-clusters (typically $5-30 \mathrm{~nm}$ diameter) that are rich in incompatible elements, including unsupported radiogenic $\mathrm{Pb}$, were first identified in high-temperature zircon [Kusiak et al., 2013a, 2013b, 2015] and later in a Hadean zircon [Valley et al., 2014]. The resulting "lumpy lead" and other trace element clusters have been interpreted to represent metamorphic mobilization into radiation damage domains (e.g., as caused by recoil of heavy nuclei during decay). Atom probe tomography of nano-clusters in zircon that experienced low-grade metamorphic overprinting shows that clusters are radially zoned in incompatible elements [Valley et al., 2014]. In contrast, high-resolution transmission electron microscopy of zircon heated to UHT metamorphic conditions [Kusiak et al., 2015] revealed that $\mathrm{Pb}$ occurs as metallic $\mathrm{Pb}$ droplets within Ti- and Al-rich amorphous domains, probably the result of melting, and is bound by partially to completely annealed domains. Kusiak et al. [2015] suggested that cluster distribution relative to the healed domains indicates structural recovery whereby an annealing front that initiated at the margins of undamaged zircon forced migration and concentration of incompatible trace elements into the most damaged locations (i.e., somewhat analogous to the industrial process of zone refining). Although spacing of nano-clusters $(20-50 \mathrm{~nm}$ spacing) within zircon domains that are now relatively enriched in $\mathrm{U}+\mathrm{Th}$ might not bias SIMS or LA-ICP-MS ages (e.g., Valley et al. [2014]), localized variability on the scale of SIMS measurements has been reported and linked directly to $\mathrm{Pb}$ nano-clusters, leading to reverse and normal discordance [Kelly et al., 2010].

\subsection{EXAMPLES}

\subsubsection{UHP Metamorphism: Inclusion Assemblages}

Arguably, the most significant applications of zircon geochronology linked with inclusion assemblages constrain the timing and rates of UHP metamorphism. Many UHP terranes have been investigated chronologically using zircons that contain inclusions of coesite or diamond. Indeed, zircon's unusual physical strength provides a resilient pressure vessel for the preservation of these rare minerals [e.g., Sobolev and Shatsky, 1990; Liou et al., 1998; Katayama and Maruyama, 2009; Liu and Liou, 2011], which otherwise are prone to invert to quartz and graphite during cooling and exhumation. Two examples from the Kokchetav and Dabie-Sulu terranes illustrate important principles (Fig. 2.8). 
(a)

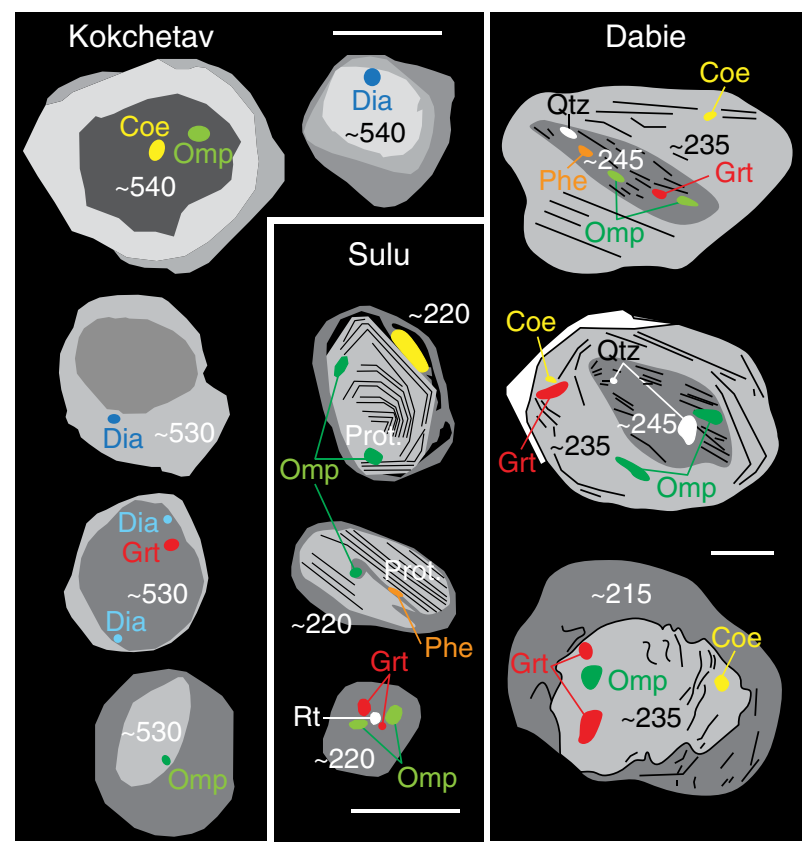

(b)

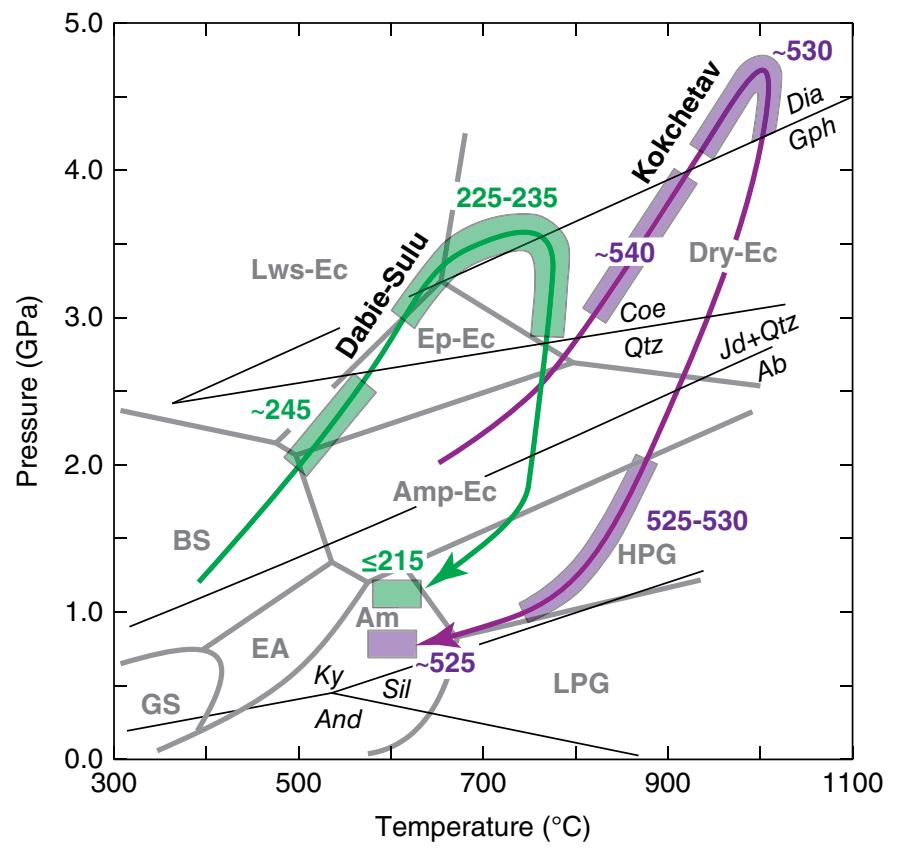

Figure 2.8 (a) Sketches of BSE and CL images of zircon grains from the Kokchetav massif [Hermann et al., 2001; Katayama et al., 2001] and the Dabie-Sulu orogen [Zhang et al., 2006, 2009; Liu and Liou, 2011], illustrating different generations of zircon and their inclusions. Numbers reflect approximate ages in Ma. For Sulu zircon, thin lines indicate internal zoning of relict, magmatic, Proterozoic cores ("Prot."). Cryptic dissolution and reprecipitation of zircon cores along cracks during metamorphism has allowed Proterozoic cores to now harbor ca. $220 \mathrm{Ma}$ eclogite-facies minerals [so-called pseudo-inclusions: Gebauer et al., 1997]. For Dabie zircon, thin lines indicate internal zoning of metamorphic zircon, arguably mimicking matrix textures. Scale bars are all $100 \mu \mathrm{m}$. (b) P-T diagram illustrating ranges of P-T conditions over which distinctive inclusion assemblages are thought to have been entrapped for Kokchetav and Dabie-Sulu rocks. Mineral abbreviations: Ab, albite; And, andalusite; Coe, coesite; Dia, diamond; Gph, graphite; Grt, garnet; Jd, jadeite; Ky, kyanite; Omp, omphacite; Qtz, quartz; Rt, rutile; and Sil, sillimanite. Facies abbreviations: Am, amphibolite; Amp-Ec, amphibole eclogite; BS, blueschist; Dry-Ec, dry eclogite; EA, epidote amphibolite; Ep-Ec, epidote eclogite; GS, greenschist; HPG, high-pressure granulite; LPG, low-pressure granulite; and Lws-Ec, lawsonite eclogite.

The Kokchetav complex exposes a thin $(<1 \mathrm{~km})$ thrust sheet of UHP rocks [Kaneko et al., 2000] that are distinguished by metamorphic diamond-bearing rocks that formed at extreme P-T conditions: $\geq 4.5 \mathrm{GPa}$ and ca. $1000^{\circ} \mathrm{C}$ [Sobolev and Shatsky, 1990; Zhang et al., 1997; Hermann et al., 2001; Katayama et al., 2001; Auzanneau et al., 2006; Katayama and Maruyama, 2009; Stepanov et al., 2016]. Parkinson et al. [2002] provide a valuable overview of the geology, mineralogy, petrology, and tectonics of these unusual rocks. Zircons formed in multiple stages (Fig. 2.8a). Older cores (ca. $540 \mathrm{Ma}$ ) contain coesite and omphacite inclusions but lack diamond. Intermediate-age mantle domains (ca. $530 \mathrm{Ma}$ ) contain diamond inclusions. Young rim domains $(525-530 \mathrm{Ma})$ contain granulite- and amphibolite-facies inclusions. Muscovite and biotite ${ }^{40} \mathrm{Ar} /{ }^{39} \mathrm{Ar}$ cooling ages are ca. 516-517 Ma [Shatsky et al., 1999]. Evidently, at least $100 \mathrm{~km}$ of exhumation occurred from diamond-bearing to amphibolite-facies conditions within a few million years, that is, at plate-tectonic rates of $\mathrm{cm} /$ year. Typical analytical uncertainties of ca. $1 \%$ restrict chronologic resolution to ca. $\pm 5 \mathrm{Ma}$ for these in situ analyses, which limits interpretational resolution. For example, exhumation rates could have ranged from virtually instantaneous to perhaps as little as $1 \mathrm{~cm} /$ year (which, while still fast, is documented in several other orogens). Prograde subduction rates are less well constrained because of uncertainties in ages and inclusion P-T conditions.

The Kokchetav rocks also reached unusually high temperatures, which raises the question: how long could they have resided at these temperatures before $\mathrm{Pb}$ diffusion reset zircon core ages? Somewhat older ages in zircon cores suggest resilience to resetting, even at temperatures of ca. $1000^{\circ} \mathrm{C}$, but do not rule out the possibility of partial diffusional resetting. Fifty to ninety percent loss from the core of a sphere occurs at values of $D t / a^{2}=0.14-0.30$, 
where $D$ is diffusivity, $t$ is time, and $a$ is the radius of the sphere [Crank, 1975, his Eq. 6.19]. Experimental estimates of $\mathrm{Pb}$ diffusion suggest diffusivities of ca. $100 \mu \mathrm{m}^{2} /$ $\mathrm{Ma}$ at $1000^{\circ} \mathrm{C}$ [Cherniak and Watson, 2001]. Thus, diffusional modification of $\mathrm{Pb}$ on length scales of ca. $50 \mu \mathrm{m}$ (Fig. 2.8a) should occur on timescales of 3-6 Ma. Although this duration may appear short, expected heating rates and durations at maximum $T$ in subduction zones are $50-100^{\circ} \mathrm{C} / \mathrm{Ma}$ and $1-2 \mathrm{Ma}$, respectively [e.g., Gerya et al., 2002; Warren et al., 2008], and exhumation and cooling from maximum P-T conditions to amphibolite-facies conditions occurred in $\leq 5 \mathrm{Ma}$ (Fig. 2.8b). Although some diffusional resetting of zircon cores may have occurred, preservation of ages is consistent with a rapid UHP cycle, as inferred theoretically and from the exhumation portion of the P-T-t path.

In eastern China, UHP rocks are exposed in two major blocks, the Dabie and Sulu blocks, which are offset along the $\sim$ NNE-striking, left-lateral, Tan-lu fault [e.g., Wang et al., 1989]. Metamorphism of both blocks is commonly presumed to have occurred together during Triassic northward subduction of the Yangtze craton beneath the Sino-Korean craton. Liu and Liou [2011] and Liou et al. [2012] provide excellent overviews of inclusion assemblages in zircon and overall metamorphic evolution. Broadly speaking, three different metamorphic domains in zircon can be identified based on CL character and inclusion assemblages (Fig. 2.8a). A core domain, ca. $245 \mathrm{Ma}$, contains inclusions of omphacite and quartz, indicating sub-UHP eclogitefacies conditions. Intermediate-age 225-235 Ma overgrowths contain inclusions of coesite, indicating UHP conditions. Zircon rims range in age from ca. 220 to ca. $210 \mathrm{Ma}$. The ca. $220 \mathrm{Ma}$ rims from Sulu rocks contain coesite inclusions [Zhang et al., 2006, 2009], whereas younger $210-215 \mathrm{Ma}$ rims from both Dabie and Sulu contain inclusions of amphibole, plagioclase, and quartz. Although diamond is well documented from the Dabie block [e.g., Xu et al., 1992; Okay, 1993], it has not yet been found as inclusions in zircon, despite intense scrutiny (over 50,000 zircons from over 3000 samples; Liou et al. [2012]). Evidently, the Dabie-Sulu rocks experienced protracted UHP conditions for at least $10 \mathrm{Ma}$, and possibly $15 \mathrm{Ma}$ for Sulu (Fig. 2.8b). Exhumation from latest UHP conditions at $220 \mathrm{Ma}$ (Sulu) or $225 \mathrm{Ma}$ (Dabie) to amphibolite- or lowergranulite facies conditions at $215 \mathrm{Ma}$ must have occurred at rates of ca. $1 \mathrm{~cm} /$ year.

Some inherited zircon cores from Sulu have igneous CL characteristics and yield Proterozoic ages, but also appear to contain inclusions of eclogite-facies minerals such as omphacite and phengite (Fig. 2.8a). High-resolution CL imaging shows that some of these inclusions occur along thin embayments or cracks that link the inclusions to eclogite-facies zircon rims. That is, the inclusions do not represent Proterozoic eclogite-facies metamorphism; rather, they must have formed during the Triassic. Gebauer et al. [1997] observed similar textures in zircon from the Dora Maira massif, Italian Alps, where UHP metamorphism occurred at ca. $35 \mathrm{Ma}$, and coesite inclusions occur inside ca. $275 \mathrm{Ma}$ magmatic zircon cores. Terming them "pseudo-inclusions," Gebauer et al. [1997] reasoned that the original zircon core fractured and partially dissolved, eclogite-facies minerals precipitated, and fractures then healed, entombing the UHP inclusions in the inherited cores. As Zhang et al. [2006] show, sufficient new zircon might precipitate along the healed fracture to be identifiable in CL images, but in other cases either no new zircon precipitates, or is so thin that it cannot be easily imaged. Such observations recommend the use of additional criteria, such as trace element patterns, for linking a dated zircon domain with metamorphic P-T conditions.

\subsubsection{Ultrahigh Temperature Processes: Trace Element Geochemistry}

The physical robustness of zircon during many metamorphic processes and its resilience to $\mathrm{Pb}$-diffusion has meant that this chronometer, perhaps more than any other, has been targeted for dating high-temperature processes. For example, in the Napier Complex of East Antarctica, zircon has largely preserved $>3900 \mathrm{Ma}$ ages of igneous zircon cores even through a protracted UHT metamorphic event at ca. 2590-2500 Ma [Black et al., 1986; Harley and Black, 1997; Kelly and Harley, 2005]. However, the addition of minor and trace element geochemistry transforms zircon in this and other UHT terranes into a powerful chronometer for addressing the nature and tempo of high-temperature processes in the deep crust.

\subsubsection{Example: Trace Element Geochemistry}

A study of a metasedimentary migmatite from the Lapland Granulite Belt (LGB) illustrates the utility of using in situ analysis (in thin sections) to integrate textural context with zircon (and major mineral) geochemistry. The LGB, located in northeast Finland, formed concurrently with Svecofennian collisions in the Paleoproterozoic [Tuisku and Huhma, 1999; Daly et al., 2001; Tuisku et al., 2006]. Juvenile metasedimentary rocks (dominantly graywackes) were intruded by enderbite and norite-enderbite magmas ca. 1920-1905 Ma and metamorphosed to medium- and high-pressure granulite facies, reaching conditions of biotite-dehyration melting $\left[750-850^{\circ} \mathrm{C}, 0.5-0.85 \mathrm{GPa}\right.$; Tuisku et al., 2006]. Monazite ages suggest metamorphic growth between 1910 and $1906 \mathrm{Ma}$, whereas zircon ages cluster at $1895 \pm 6 \mathrm{Ma}$ 
[Tuisku and Huhma, 2006]. The younger zircon ages were originally interpreted to reflect growth during crystallization of melts during cooling of the migmatites.

Previously unpublished data from an equivalent sample can shed light on this suggestion. The sample of leucocratic garnet-sillimanite-bearing migmatite contains garnet porphyroblasts that are locally euhedral (Fig. 2.9a). Biotite occurs both as inclusions in garnet and locally as coarse-grained overgrowths (retrograde) on garnet. Garnet is chemically zoned, with more almandine- and Y-rich rims $\left(X_{\mathrm{Alm}}=0.73\right.$ at rims vs 0.64 in cores; $\mathrm{Y}_{2} \mathrm{O}_{3}$ increases from 0.02 to $0.10 \mathrm{wt} \%$ within $\sim 100 \mu \mathrm{m}$ of the rim; Fig. 2.9b). Zircon occurs in leucosome, as inclusions in garnet, and as partial inclusions in garnet rims (Fig. 2.9a). Zircon grains are zoned, commonly characterized by round, BSE-bright cores, moderate-BSE mantles, and euhedral rims that have sector zoning and planar banding (Fig. 2.9c and d). Where zircon is embedded in garnet rims, overgrowths are limited or absent within garnet, but are well developed near the garnet edge and into the immediate matrix domain (Fig. 2.9a and c). Zircon cores, mantles and rims have $\mathrm{Pb}-\mathrm{Pb}$ ages that overlap within $2 \sigma$ uncertainty $(1901 \pm 9,1893 \pm 6,1895 \pm 3 \mathrm{Ma}$, respectively). Zircon cores are characterized by $\mathrm{Th} / \mathrm{U} \approx 0.35$ and Ti-in-zircon temperatures of $\sim 800^{\circ} \mathrm{C}$. In comparison, zircon rims are characterized by $\mathrm{Th} / \mathrm{U} \approx 0.2$ and $\mathrm{Ti}$-inzircon temperatures of $\sim 700^{\circ} \mathrm{C}$, suggesting that the zircon rims grew during cooling and crystallization of melt within the migmatite.

Of particular interest is the timing of zircon growth relative to garnet, which can be investigated using texturally constrained REE analysis. The BSE bright cores of zircon have flat-HREE patterns in chondrite-normalized plots $\left(\mathrm{Yb} / \mathrm{Gd}_{\mathrm{N}} \approx 0.9\right)$, in contrast to steep-HREE patterns in zoned zircon rims $\left(\mathrm{Yb} / \mathrm{Gd}_{\mathrm{N}} \approx 10.2\right.$; Fig. 2.9e). Garnet cores, which have flat-HREE patterns, contrast with garnet rims that are HREE-rich $\left(\mathrm{Yb} / \mathrm{Gd}_{\mathrm{N}}=1.2\right.$ and 13.6, respectively) and have more pronounced negative $\mathrm{Eu}^{*}$ ( 0.03 in cores vs 0.12 in rims; Fig. 2.9e). Calculated $D_{\mathrm{HREE}}^{\mathrm{Zrn} / \mathrm{Grt}}$ values (Fig. 2.9f) are $\sim 1$ for zircon and garnet cores, and just above 1 for analyses of zircon and garnet rims. The spot size of the ion microprobe $(\sim 20 \mu \mathrm{m}$ in this study) limits the ability to accurately track concentrations closer to the grain boundary. However, using $Y$ concentration data analyzed by electron microprobe $(1 \mu \mathrm{m} \mathrm{spot})$, the relative HREE enrichment at the garnet rim can be calculated. Using this value gives $D_{\mathrm{HREE}}^{\mathrm{Zr} / \mathrm{Grt}} \approx 1$ for zircon and garnet rims. If one accepts the experimental data of Taylor et al. [2015; $D_{\mathrm{HREE}}^{\mathrm{Zrn} / \mathrm{Grt}} \approx 1$ for equilibrium growth], these data, integrated with $\mathrm{Th} / \mathrm{U}$ and Ti-in-zircon temperatures, suggest that zircon cores grew (or recrystallized) in equilibrium with garnet cores at close to peak metamorphic conditions, whereas zircon and garnet rims grew during cooling and crystallization of melt. Although the uncertainties on $\mathrm{U}-\mathrm{Pb}$ ages for Paleoproterozoic rocks preclude the duration of metamorphism and/or melting to be estimated, similar textural and chemical data from a younger terrane could yield important insights into melting processes in migmatites.

\subsubsection{Continuous Growth Versus Resetting of $U-P b$ ?}

Calculations of $\mathrm{Pb}$ diffusivity in zircon (above) suggest that protracted periods spent at high or UHT metamorphic conditions could partially or completely reset $\mathrm{U}-\mathrm{Pb}$ ages. Minor-to-substantial Pb-loss is apparent in zircon data from orthogneiss samples from the Napier Complex, east Antarctica [Black et al., 1986; Harley and Black, 1997; Kelly and Harley, 2005], where UHT metamorphism reached peak conditions of $\sim 1070^{\circ} \mathrm{C}$ at pressures $\geq 1.0 \mathrm{GPa}$ [Harley and Motoyoshi, 2000; Harley, 2008], with near-isobaric cooling at $\sim 0.8-1.0 \mathrm{GPa}$ after an initial phase of decompression at $T>1000^{\circ} \mathrm{C}$ [Hollis and Harley, 2002]. The minimum age for reaching peak UHT conditions is bracketed by a ca. $2590 \mathrm{Ma}$ leucosome that cuts UHT assemblages [Harley et al., 2001], extending to at least ca. 2545 Ma [Kelly and Harley, 2005]. Zircon ages from leucosomes range between ca. 2510 and ca. $2470 \mathrm{Ma}$ [e.g., Hokada and Harley, 2004; Kelly and Harley, 2005], and likely reflect crystallization of partial melts during cooling below the solidus. However, the data imply that rocks resided at UHT conditions for at least $45 \mathrm{Ma}$, with a duration at $>750^{\circ} \mathrm{C}$ likely approaching 100 Myrs. Despite these protracted durations at somewhat extreme conditions, some zircon grains preserve remarkably consistent, ancient $\mathrm{U}-\mathrm{Pb}$ ages, indicating that $\mathrm{Pb}$ diffusion might be slower than indicated in experiments.

Despite the view that the Earth's crust rarely experiences UHT conditions, understanding UHT behavior is geodynamically important. HT-UHT metamorphic terranes represent exhumed sections of the deep crust where metamorphism may have occurred during collisional or extensional tectonic events. Our understanding of such tectonic processes, on a regional or more theoretical level, requires robustly placing absolute ages on the timing of events, linking these to processes, and thereby constraining event duration [e.g., Harley, 2016]. Where the deep crust reaches UHT conditions $\left(>900^{\circ} \mathrm{C}\right)$, it is crucial to know if such temperatures are merely fleeting or occurred over protracted periods. How can thickened crust be stabilized if the deeper levels are weak? Dating zircon in HT-UHT terranes provides a basis for models describing how the crust actually gets this hot, and what the implications are for the stabilization of the crust in, for example, mountain belts.

The Proterozoic evolution of the Eastern Ghats Province, India, represents several crustal provinces and collision events that date back into the Mesoproterozoic [Rickers et al., 2001; Dobmeier and Raith, 2003], but is 
(a)

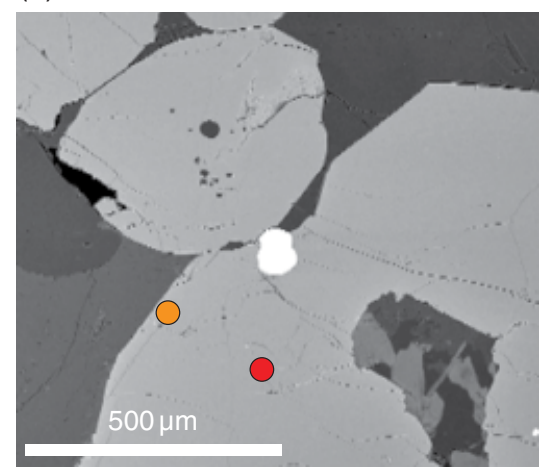

(c)

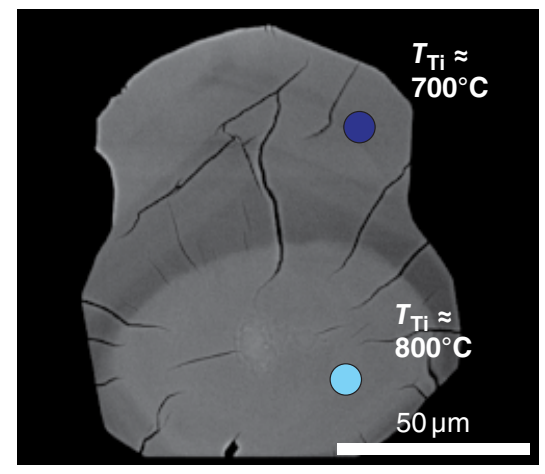

(e)
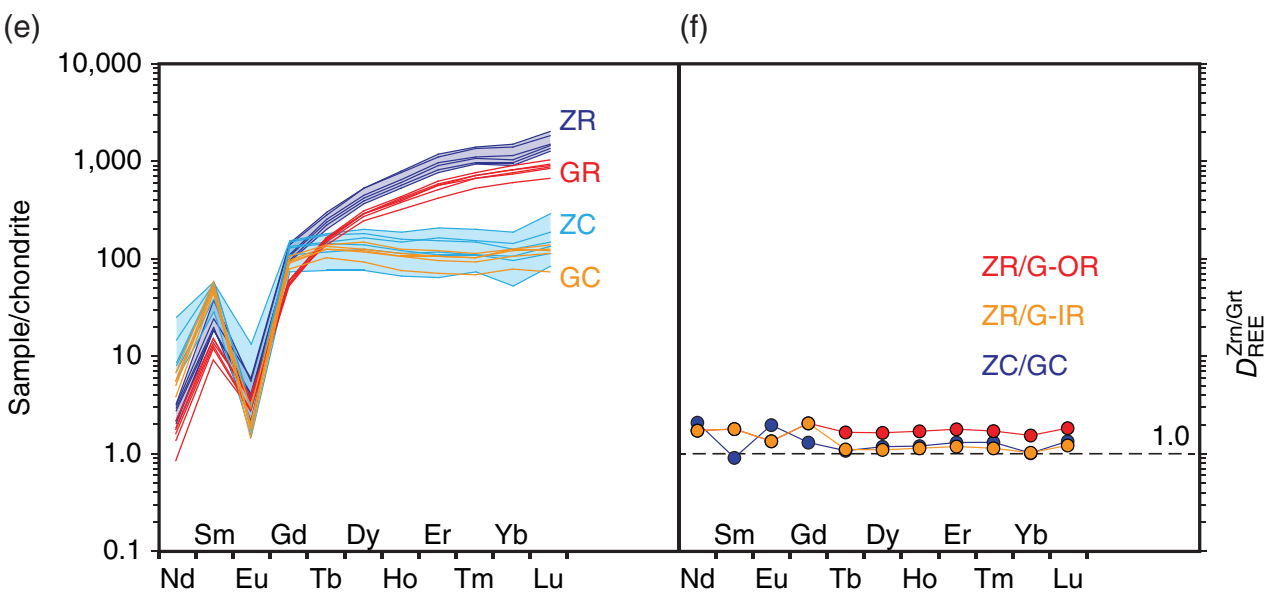

(g)

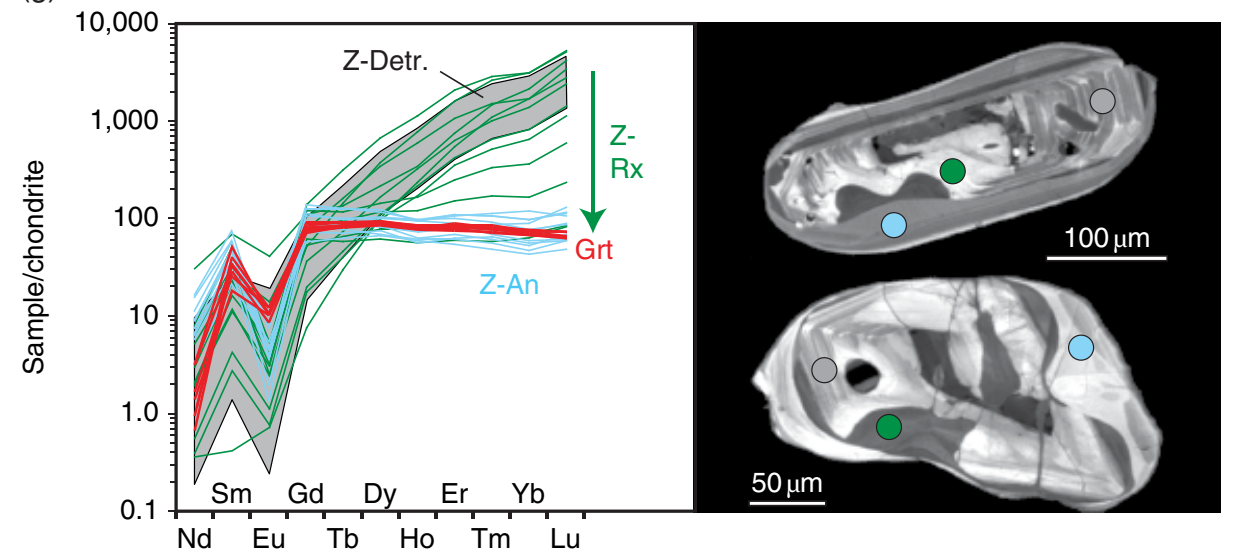

(b)

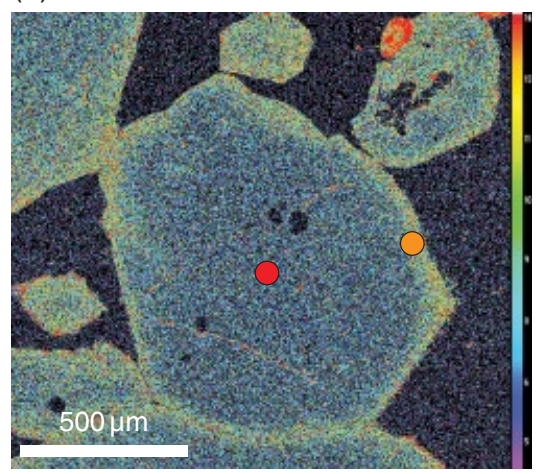

(d)

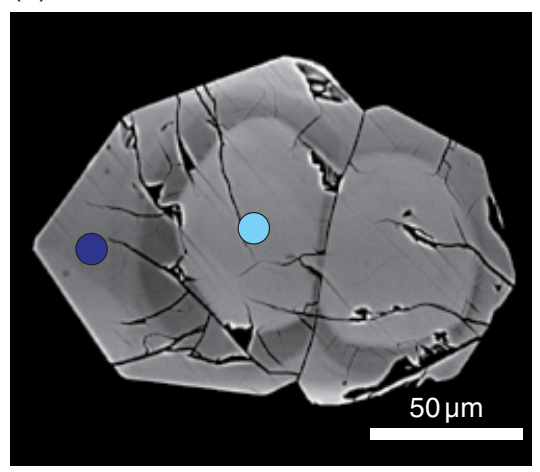

(f) 
dominated by HT-UHT metamorphism that affected the complex in the early Neoproterozoic [Grew and Manton, 1986; Bhattacharya et al., 2003; Simmat and Raith, 2008; Das et al., 2011; Korhonen et al., 2011; Bose et al., 2011]. Disagreement over the timing and duration of UHT metamorphism in part reflects a complex array of published ages (up to $100 \mathrm{Ma}$ duration; see summary in Korhonen et al. [2013]) that contribute to contrasting interpretations of the P-T history: Was the terrane affected by polyphase metamorphism, or a single protracted event? From a zircon perspective, do ages represent growth phases along a single P-T path, or instead represent partial resetting of zircon during a polyphase metamorphic history?

The Eastern Ghats Province experienced metamorphism reaching peak UHT conditions $>950^{\circ} \mathrm{C}(\mathrm{P}>0.8 \mathrm{GPa})$ followed by initial cooling before ca. $980 \mathrm{Ma}$ [Korhonen et al., 2011], possibly before $\sim 1100 \mathrm{Ma}$ [Korhonen et al., 2013]. A later granulite-facies event as young as $690 \mathrm{Ma}$ is also documented in the western margin of the province [Hippe et al., 2016]. A near-isobaric cooling P-T path [Korhonen et al., 2011] suggests stabilization of thickened, very hot crust. Zircon ages within and among samples range from ca. $980 \mathrm{Ma}$ to $<930 \mathrm{Ma}$ and were interpreted to reflect zircon growth at different times along the cooling path [Korhonen et al., 2013]. Compositionally distinct melts with different solidus temperatures could segregate within a single rock and crystallize at different temperatures and times. If so, the large age range represents sustained UHT conditions (ca. $50 \mathrm{Ma}$, comparable to the Napier Complex) during slow cooling $\left(\sim 1^{\circ} \mathrm{C} / \mathrm{Myr}\right)$. Monazite preserves analogous age variations and sharp compositional domain boundaries that preclude substantial diffusive exchange [Korhonen et al., 2013]. While experimental diffusion data suggest that partial U-Pb resetting could have occurred in zircon, most data point to growth and age preservation at HT-UHT conditions over extended timescales.

\subsubsection{Resetting of REE at UHT Conditions?}

Diffusivity of REE in zircon increases with decreasing ionic radius (the HREE diffuse faster than the LREE), and is comparable to, but slower than, $\mathrm{Pb}$ for $T \leq \sim 1100^{\circ} \mathrm{C}$ [Cherniak et al., 1997; Cherniak and Watson, 2001]. These differences in the diffusion rate may account for preservation of zoning in CL images (CL zoning in zircon commonly correlates with REE zoning) even for zircon grains that have experienced extensive Pb-loss [e.g., Harley and Kelly, 2007; Kotková et al., 2016]. Modification of REE compositions may be possible at more extreme metamorphic conditions, and/or where zircon is modified through recrystallization.

In a garnet-bearing paragneiss from the Napier Complex, east Antarctica, detrital cores with preserved oscillatory zoning have steep REE patterns consistent with igneous zircon, while thick banded overgrowths, suggestive of growth from anatectic melt, have flat, HREE-depleted patterns [Fig. $2.9 \mathrm{~g}$; Kelly and Harley, 2005]. However, where the core domains have undergone modification, recrystallization through dissolution-reprecipitation reactions (dark embayments or curved to convoluted zoning) or annealing of strained domains (blurred oscillatory zoning), compositions show a progressive resetting of the HREE from steep to flat patterns (Fig. 2.9 g). Preservation of steep HREE patterns in cores where igneous zoning is preserved indicates that REE diffusion is still sluggish even at UHT conditions. However, recrystallization may cause zircon to approach equilibrium with the local metamorphic assemblage, in this case garnet.

\subsubsection{Metamorphic Fluid Flow}

Researchers commonly presume that aqueous fluids can catalyze dissolution-reprecipitation of metamorphic zircon [e.g., Liermann et al., 2002; Tomaschek et al., 2003; Rubatto and Hermann, 2003b]. Experiments and some

Figure 2.9 Integration of textural, $\mathrm{U}-\mathrm{Pb}$, and trace element data to constrain high-temperature metamorphic processes. Shaded dots in images correspond with shaded trace element patterns. (a to f) Texturally constrained analysis of zircon and garnet from a metasedimentary migmatite from the LGB, Fennoscandian shield, Finland. (a) BSE image of zircon (see Fig. 2.9c) partially enclosed by garnet. (b) Y element map of euhedral garnet showing Y-enriched rims. (c) BSE image of zoned zircon within a garnet edge: round, bright cores are rimmed by darker mantles and rims that have planar banding and sector zoning. Outer rims are commonly euhedral. (d) BSE image of a zoned zircon from a leucosome domain, with well-developed euhedral rims. (e) Chondrite-normalized REE compositions of zircon and garnet: GC, garnet cores; GR, garnet rims; ZC, zircon cores; and ZR, zircon rims. Data normalized using the chondrite values of Anders and Grevasse [1989]. (f) $D_{\mathrm{REE}}^{\mathrm{Zr} / \mathrm{Grt}}$ values for analyses of the Lapland migmatite zircon and garnet. ZC, ZR, and GC as for Figure 2.9e, G-IR represents measured garnet rim values as proximal to the grain boundary as possible by ion microprobe; G-OR represents garnet compositions as extrapolated from $Y$ zoning measured by electron microprobe. Both $D_{\mathrm{REE}}^{\mathrm{Zr} / \mathrm{Grt}}$ are $\sim 1$. (g) Equilibration of HREE compositions in zircon during garnet-present UHT metamorphism in a paragneiss. Detrital magmatic zircon (Z-Detr.) is locally recrystallized (Z-Rx; dark zones and domains of blurred oscillatory zoning in zircon cores) with HREE patterns progressively depleted toward compositions similar to that in zircon grown from anatectic melt (Z-An) and garnet (Grt). 
natural data do indicate substantial zircon reactivity and solubility in extremely alkaline, acidic, or salty aqueous fluids [Sinha et al., 1992; Rizvanova et al., 2000; Tsujimori et al., 2005], especially if zircon is metamict [Schmidt, 2006]. Whether more typical low salinity, quasi-neutral $\mathrm{pH}$ fluids also catalyze zircon dissolution-reprecipitation at moderate metamorphic conditions (e.g., $500-600^{\circ} \mathrm{C}$ ) remains debatable. Some zircon in sub-anatectic rocks exhibits distinct metamorphic overgrowths, particularly at high pressure [e.g., Liermann et al., 2002; Tomaschek et al., 2003], whereas other zircon does not [e.g., Williams, 2001; Vorhies et al., 2013]. Intragrain microporosity is considered a diagnostic indicator for aqueous replacement reaction [Putnis, 2002]. While these textures are rarely reported in natural zircon [Tomaschek et al., 2003; Xie et al., 2005], they have been reproduced in experiments at ca. $600^{\circ} \mathrm{C}$ in high-Cl solutions [Geisler et al., 2003]. Directly linking zircon growth to fluid flow requires independent criteria, preferably both textural (e.g., neoblastic zircon in veins) and geochemical.

In addition to trace elements, researchers increasingly employ oxygen isotopes of zircon to investigate fluid flow. With the advent of routine, in situ, $\delta^{18} \mathrm{O}$ measurements using SIMS (e.g., see review of Valley and Kita [2009]), oxygen isotope analyses can be spatially correlated, sometimes even co-located, with trace element and $\mathrm{U}-\mathrm{Pb}$ analyses. Zircon fractionates oxygen isotopes similarly to Ca-poor garnet [Valley et al., 2003], so models of garnet isotopic behavior proxy for zircon. Such models have been developed for closed system metamorphism [Kohn, 1993], and the principles are summarized here as a reference for identifying open-system, fluid-mediated processes.

Very generally, $\delta^{18} \mathrm{O}$ values of garnet and zircon are lower than nearly all whole rocks. As temperature increases, isotope fractionations between minerals decrease, including the fractionation factors for garnet relative to whole rock and zircon relative to whole rock. Thus, if the whole-rock $\delta^{18} \mathrm{O}$ is fixed (closed-system behavior), and temperature increases, garnet and zircon $\delta^{18} \mathrm{O}$ must increase. Rayleigh fractionation of relatively low $\delta^{18} \mathrm{O}$ values in garnet interiors augments this isotopic trend, whereas loss of relatively high $\delta^{18} \mathrm{O}$ fluid diminishes it slightly. In most rocks, mineral fractionations are sufficiently small that $\delta^{18} \mathrm{O}$ values of garnet and zircon are expected to change relatively little during closedsystem metamorphism. For example, in closed isotopic systems, maximum zoning in garnet is predicted and observed to be $\leq \sim 1 \%$ in pelitic compositions and as little as $\sim 0.1 \%$ in mafic compositions [e.g., Kohn et al., 1993]. Thus, identification of fluid flow events in zircon commonly relies on finding isotopic differences that exceed the $\sim 1 \%$ range of variation expected in closed systems. However, just because one domain in a zircon differs isotopically from another does not require that fluid flow caused zircon growth, rather fluid flow and isotopic alteration could have occurred between zircon growth events.

Investigation of the Dora Maira whiteschists, Italian Alps [Gauthiez-Putallaz et al., 2016] presents an unusual case study in which growth of zircon may be linked to fluid-producing metamorphic reactions. These rocks generally reflect metamorphism of a metasomatized granite protolith [e.g., Compagnoni and Hirajima, 2001; Ferrando et al., 2009; Gauthiez-Putallaz et al., 2016], reaching peak UHP conditions of $\sim 725^{\circ} \mathrm{C}, \sim 4 \mathrm{GPa}$ [e.g., Chopin, 1984; Schertl et al., 1991; Hermann, 2003; Castelli et al., 2007; Ferrando et al., 2009]. Gauthiez-Putallaz et al. [2016] investigated two different bulk compositions: a Si-rich rock (ca. 50\% quartz) and a Si-poor rock (ca. 5\% quartz). Zircon contains Permian igneous cores, similar to zircons from adjacent un-metasomatized granite [Gebauer et al., 1997], with $\delta^{18} \mathrm{O}$ values of ca. $10 \%$. Cores are overgrown with either one metamorphic domain (Si-rich rock) or two metamorphic domains (Si-poor rock) with indistinguishable $\delta^{18} \mathrm{O}$ values of ca. $6.5 \%$ and indistinguishable ages of ca. $35 \mathrm{Ma}$ (Fig. 2.10a). Lanthanides show a range of patterns, from steep HREE in zircon cores to flat or even negatively sloped HREE in some zircon overgrowths (Fig. 2.10b). As discussed previously, the flattening of HREE in zircon is commonly interpreted to reflect fractional crystallization of garnet [Rubatto, 2002; Whitehouse and Platt, 2003].

Lanthanide patterns and mineral inclusions in zircon from the low-Si rock provide the most direct constraints on the timing of zircon growth relative to the P-T path and mineral reactions. The inner zircon overgrowth in these rocks contains inclusions of phlogopite and has a steep REE pattern, similar to protolith zircon, except that the overgrowth lacks a pronounced Eu-anomaly. Together with phase equilibrium constraints (Fig. 2.10c), these observations suggest that the inner zircon overgrowth formed in a phlogopite-stable region, but with minimal garnet (e.g., point Z1, Fig. 2.10c).

Assuming Rayleigh fractionation, we propose here that the Lu contents of garnet and zircon can be modeled as a function of garnet mode [Kohn, 2009], and linked to phase equilibrium models of garnet mode along the P-T path [Gauthiez-Putallaz et al., 2016]. Phase equilibrium modeling and thin section observations indicate that garnet occupied ca. $40 \%$ of the rock volume at the peak of metamorphism, whereas zircon REE trends indicate that $\mathrm{Lu}$ contents decreased in the reactive rock by a factor of $\sim 500$, presumably driven by garnet growth. These observations constrain the $\mathrm{Lu}$ fractionation factor between garnet and whole rock to $\sim 13$, and allow $\mathrm{Lu}$ contents in zircon to be related to the P-T path. For example, $\mathrm{Lu}$ is predicted to decrease by a factor of $\sim 10$ when garnet reaches a mode of $\sim 18 \%$. This mode is predicted to occur 
(a)

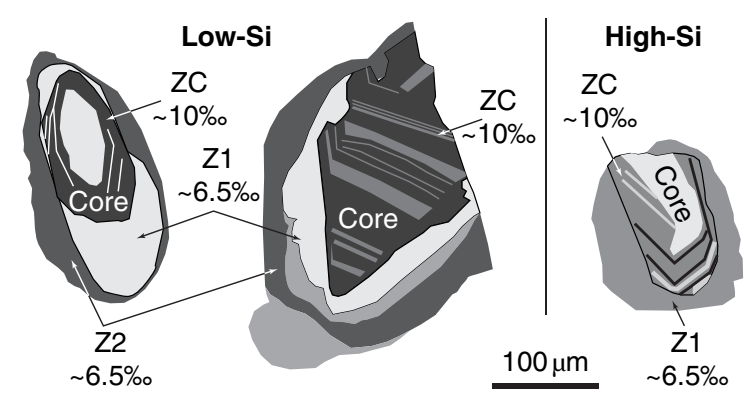

(b)

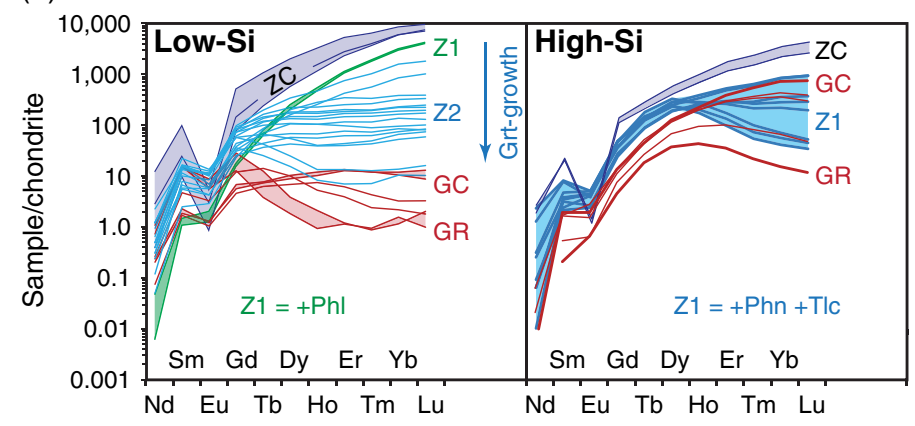

(c)

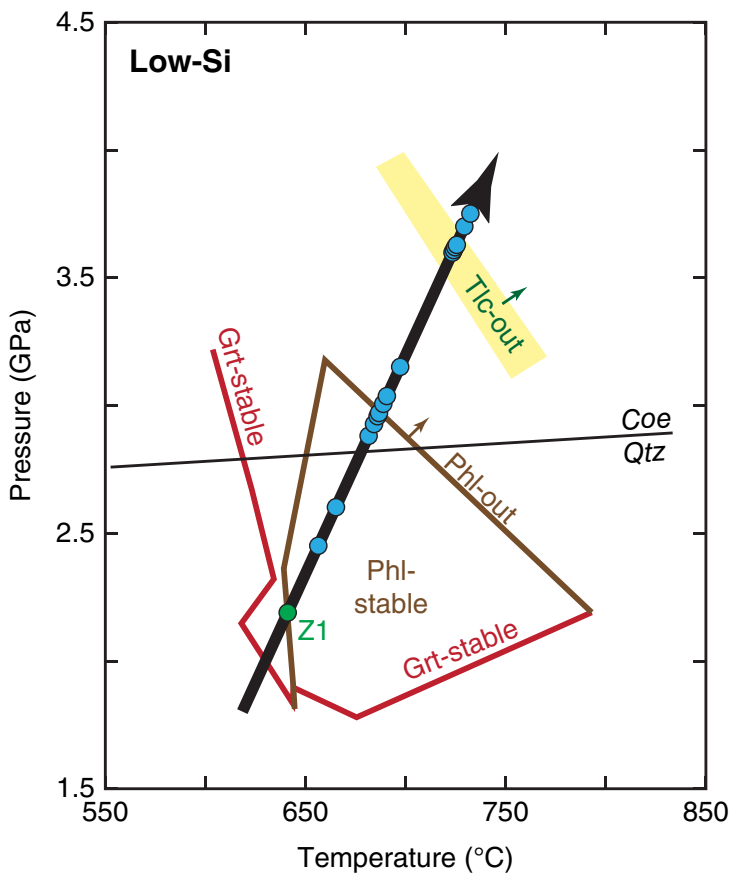

Figure 2.10 Links between zircon growth and metamorphic fluid production. Data from Gauthiez-Putallaz et al. [2016] for Si-rich and Si-poor rocks of the Dora Maira massif. (a) Zircon contains Permian igneous cores, with two stages of zircon overgrowth in Si-poor rocks, and one-stage of zircon overgrowth in Si-rich rocks. Oxygen isotope values for igneous cores are ca. 3.5\% higher than metamorphic overgrowths. Z1, first stage overgrowth; Z2, second stage overgrowth, and ZC, zircon core. (b) REE patterns are steep for protolith cores and first-stage overgrowths for Si-poor rocks. Progressive growth of garnet ("Grt-growth") and consequent fractionation of HREE develops flat or even negatively sloped HREE patterns in later zircon overgrowths. GC, garnet core and GR, garnet rim. In low-Si rocks, Z1 contains inclusions of phlogopite (Phl), whereas in high-Si rocks, Z1 contains inclusions of phengite (Phn) and talc (Tlc). (c) P-T diagram showing proposed P-T path and key reactions for low-Si rock. Z1 formed when garnet mode was low, in the phlogopite-stable field. Modeling of Lu fractionation combined with phase equilibrium modeling allows P-T conditions of different zircon compositions to be inferred (dots). These points cluster around the phlogopite-out and talc-out reactions, which are major water-producing reactions in these rocks.

at $P \sim 2.9 \mathrm{GPa}$ [Gauthiez-Putallaz et al., 2016]. So zircon with a Lu content 10 times lower than the inner overgrowth would plot at $2.9 \mathrm{GPa}$. Modeling the REE data for the Si-poor rock, most zircon compositions plot closely to the phlogopite-out and talc-out reactions. The largest releases of water in the low-Si rock occur at these reactions, and at the phlogopite-in reaction, which is approximately where the inner zircon overgrowth is thought to have formed. This correspondence between zircon growth and fluid release provides prima facie evidence that dehydration reactions do catalyze zircon growth. For the silica-rich rock, nearly all garnet growth occurs at the talc-out reaction, so zircon overgrowths all closely correspond with that reaction.

What do zircon oxygen isotopes reveal about fluid flow? If zircon cores reflect the original protolith composition, the $\geq 3 \%$ o lower $\delta^{18} \mathrm{O}$ values in metamorphic rims cannot reflect closed-system processes. The original protolith composition must have changed, likely through metasomatism. Such a change must have occurred after intrusion of the granite protolith, and prior to initial zircon growth at $600-650^{\circ} \mathrm{C}$, but is otherwise temporally unconstrained. Gauthiez-Putallaz et al. [2016] propose that metasomatism occurred in a high-temperature rift environment soon after intrusion, forming a kaolinite-rich rock. Pawlig and Baumgartner [2001] proposed a similar model of near-surface alteration prior to metamorphism to explain unusual occurrence of whiteschists within the Monte Rosa granite. Such alteration would fix the wholerock $\delta^{18} \mathrm{O}$ prior to metamorphism and explain why both garnet and zircon have homogeneous and indistinguishable $\delta^{18} \mathrm{O}$ values. Conversely, pronounced zoning in chemistry (primarily $\mathrm{Fe}$ ) and $\mathrm{Sr}$ isotopes in garnets from nearby outcrops suggests that metasomatism occurred during prograde metamorphism [e.g., Compagnoni and Hirajima, 2001; Sousa et al., 2013]. Such disparities in 
oxygen, $\mathrm{Fe}$, and $\mathrm{Sr}$ might be reconciled if the ratio of $\mathrm{Fe} / \mathrm{O}$ and $\mathrm{Sr} / \mathrm{O}$ in the fluid was much lower than in the original rock. Moderate fluid flux would change $\delta^{18} \mathrm{O}$ before the Fe content and $\mathrm{Sr}$ isotopes. That is, although major elements and $\mathrm{Sr}$ continued to alter metasomatically (in some rocks), a homogeneous oxygen isotope composition was established during the early stages of metamorphism, prior to zircon and garnet growth.

Homogeneous and indistinguishable $\delta^{18} \mathrm{O}$ values for zircon and garnet are consistent not only with a system buffered by external fluids but also with closed-system models of garnet and zircon growth. In the low-Si rock, zircon and garnet $\delta^{18} \mathrm{O}$ are so close to the whole rock that the maximum change in $\delta^{18} \mathrm{O}$ over the entire temperature range of garnet growth $\left(610-720^{\circ} \mathrm{C}\right)$ should be only $\sim 0.3 \%$, which is within analytical reproducibility. (Note: Gauthiez-Putallaz et al. calculate isotopic shifts up to $0.6 \%$ for this composition, but they employ inaccurate fractionation factors. Use of internally consistent experimental and empirical fractionation factors with corrections for measured chemical compositions [Kohn and Valley, 1998a, 1998b; Valley et al., 2003] reduces the calculated magnitude of isotopic zoning in garnet and zircon by a factor of $\sim 2$.) In the Si-rich rock, stronger $\sim 0.5 \%$ isotopic changes are possible in garnet and zircon because they are more different isotopically from the whole rock. The observed insignificant isotopic difference between zircon and garnet of $0.1 \pm 0.3 \%$ in the Si-rich rock is consistent with growth over a very restricted range of temperature at the talc-out reaction, and additionally rules out large, ca. $100^{\circ} \mathrm{C}$ differences in the garnet versus zircon formation temperature.

\subsection{RECOMMENDATIONS}

The principles (section 2.5) and applications (section 2.6) of zircon geochemistry have provided new insights into metamorphic processes. Also, numerous analytical and conceptual advances over the past several decades now allow the age of a zircon domain to be linked broadly to its metamorphic P-T condition, either through geochemistry (e.g., REE pattern) or through mineral inclusion assemblages. So where do we go from here? Researchers should be able to improve interpretations substantially through a better understanding of zircon geochemical systematics in the following four areas of inquiry:

1. Trace element partitioning between zircon and garnet. Two different experimental studies and several different natural studies imply quite different partitioning behavior between zircon and garnet (see summaries of Rubatto and Hermann [2007] and Taylor et al. [2015]). Garnet is especially important because, like zircon, it prefers HREE. So garnet, more than any other common metamorphic mineral, impacts zircon REE patterns. Quite possibly,
REE substitution mechanisms in zircon and garnet depend on P-T conditions or bulk composition. Before zircon trace element patterns can be fully related to metamorphic parageneses (through modeling), HREE substitution mechanisms and partition coefficients need to be quantified. Better understanding is also needed of chemical interactions between zircon and other major phases (minerals and melts) under metamorphic conditions, especially on a local scale in rocks.

2. Diffusion in zircon. Although $\mathrm{Pb}$ diffusion in zircon is quite slow, not all metamorphic zircon may be immune to diffusional resetting. Natural examples where zircon shows diffusive resetting would provide useful checks on experimental data, and potentially constrain durations at maximum temperatures or cooling rates. For example, in the Bohemian massif, peak temperatures reached $1100^{\circ} \mathrm{C}$, and were overprinted at high-pressure granulite-facies conditions with temperatures $\geq 1050^{\circ} \mathrm{C}$ [Haifler and Kotková, 2016]. Assuming experimental $\mathrm{Pb}$ diffusion rates [Cherniak and Watson, 2001], at $1100^{\circ} \mathrm{C}$ a $50 \mu \mathrm{m}$ zircon grain would reset its $\mathrm{U}-\mathrm{Pb}$ age in ca. $100 \mathrm{ka}$. Diffusional resetting logically explains why all zircon domains in these rocks yield indistinguishable ages [Kotková et al., 2016]. Close scrutiny of diffusion profiles in zircon from such a setting might provide insight into relative diffusivities of numerous elements (e.g., REE and $\mathrm{Hf}$ isotopes retain domain-scale compositional differences, whereas U-Pb ages do not) and potentially constrain temperature-time histories in other metamorphic settings.

3. Zircon growth mechanisms. Some studies show that zircon can grow at moderate temperatures, albeit high pressures [Tomaschek et al., 2003; Gauthiez-Putallaz et al., 2016], whereas other studies show virtually no zircon growth prior to partial melting [Williams, 2001; Vorhies et al., 2013]. Zircon solubility and $\mathrm{Zr}$ diffusivity seem too low to catalyze dissolution and reprecipitation, while low HREE and Y contents would not obviously destabilize zircon in favor of other minerals. Similarly, radiation damage appears to recover at temperatures above $200-350^{\circ} \mathrm{C}$ [e.g., Schmidt, 2006; Pidgeon, 2014], but perhaps protracted self-irradiation makes specific zircon domains susceptible to dissolution and recrystallization. A better understanding of zircon's variable reactivity would help petrologists interpret ages of a mineral otherwise famous for its inert chemical and physical character.

4. "Lumpy lead." The mobility of radiogenic $\mathrm{Pb}$ and other trace elements during reheating represents an opportunity to improve interpretations of chronologic and geochemical data. Understanding the mechanisms and rates of damage recovery has implications for the prograde temperature conditions over which trace elements are available for reaction, mobility of trace elements in general, modification of trace element signatures in zircon and other minerals, and preservation of zircon 
formation ages that routinely analyzed by microbeam techniques. For example, redistribution of $\mathrm{Pb}$ and other trace elements during later reheating might be used to identify timing of reheating events [Valley et al., 2014], or otherwise help interpret chronologic systematics [Kelly et al., 2010; Kusiak et al., 2013a, 2013b]. The practical application and refinement of these principles represents a new frontier in zircon research.

\section{ACKNOWLEDGMENTS}

This research was funded by NSF grants EAR-1419865 and -1545903 to MJK and EAR-0911734 to NMK. NMK acknowledges support from the John Templeton Foundation as a Theme Leader in the Collaborative for Research in Origins (CRiO). We thank Dan Harlov and Andreas Möller for comprehensive and insightful reviews, and we thank Desmond E. Moser and Fernando Corfu for expert editorial handling.

\section{REFERENCES}

Allen, C. M., and I. H. Campbell (2012), Identification and elimination of a matrix-induced systematic error in LAICP-MS ${ }^{206} \mathrm{~Pb} /{ }^{238} \mathrm{U}$ dating of zircon, Chem. Geol., 332-333, 157-165.

Anders, E., and N. Grevasse (1989), Abundances of the elements-Meteoritic and solar, Geochim. Cosmochim. Acta, 53, 197-214.

Appleby, S. K., M. R. Gillespie, C. M. Graham, R. W. Hinton, G. J. H. Oliver, N. M. Kelly, and EIMF (2010), Do S-type granites commonly sample infracrustal sources? New results from an integrated $\mathrm{O}, \mathrm{U}-\mathrm{Pb}$ and $\mathrm{Hf}$ isotope study of zircon, Contrib. Mineral. Petrol., 160, 115-132.

Auzanneau, E., M. W. Schmidt, and D. Vielzeuf (2006), Experimental evidence of decompression melting during exhumation of subducted continental crust, Contrib. Mineral. Petrol., 152, 125-148.

Ayers, J. C., L. Zhang, Y. Luo, and T. J. Peters (2012), Zircon solubility in alkaline aqueous fluids at upper crustal conditions, Geochim. Cosmochim. Acta, 96, 18-28.

Baker, D. R., A. Conte, C. Freda, and L. Ottolini (2001), The effect of halogens on $\mathrm{Zr}$ diffusion and zircon dissolution in hydrous metaluminous granitic melts, Contrib. Mineral. Petrol., 142(6), 666-678.

Ballard, J. R., J. M. Palin, and I. H. Campbell (2002), Relative oxidation states of magmas inferred from $\mathrm{Ce}(\mathrm{IV}) / \mathrm{Ce}(\mathrm{III})$ in zircon: Application to porphyry copper deposits of northern Chile, Contrib. Mineral. Petrol., 144, 347-364.

Bea, F. (1996), Residence of REE, Y, Th and U in granites and crustal protoliths; implications for the chemistry of crustal melts, J. Petrol., 37(3), 521-552.

Bernet, M., and J. I. Garver (2005), Fission-track analysis of detrital zircon, Rev. Mineral. Geochem., 58, 205-238.

Bernini, D., A. Audétat, D. Dolejš, and H. Keppler (2013), Zircon solubility in aqueous fluids at high temperatures and pressures, Geochim. Cosmochim. Acta, 119, 178-187.
Bhattacharya, S., R. Kar, W. Teixeira, and M. Basei (2003), High-temperature crustal anatexis in a clockwise P-T-t path: isotopic evidence from a granulite-granitoid suite in the Eastern Ghats Belt, India, J. Geol. Soc. Lond., 160, 39-46.

Black, L. P., I. S. Williams, and W. Compston (1986), Four zircon ages from one rock: the history of a 3,930 Ma-old granulite from Mount Sones, Enderby Land, Antarctica, Contrib. Mineral. Petrol., 94, 427-437.

Black, L. P., S. L. Kamo, C. M. Allen, D. W. Davis, J. N. Aleinikoff, J. W. Valley, R. Mundil, I. H. Campbell, R. J. Korsch, I. S. Williams, and C. Foudoulis (2004), Improved ${ }^{206} \mathrm{~Pb} /{ }^{238} \mathrm{U}$ microprobe geochronology by the monitoring of a trace-element-related matrix effect; SHRIMP, ID-TIMS, ELA-ICP-MS and oxygen isotope documentation for a series of zircon standards, Chem. Geol., 205, 115-140.

Boehnke, P., E. B. Watson, D. Trail, T. M. Harrison, and A. K. Schmitt (2013), Zircon saturation re-revisited, Chem. Geol., 351, 324-334.

Bose, S., D. J. Dunkley, S. Dasgupta, K. Das, and M. Arima (2011), India-Antarctica-Australia-Laurentia connection in the Paleoproterozoic-Mesoproterozoic revisited: Evidence from new zircon $\mathrm{U}-\mathrm{Pb}$ and monazite chemical age data from the Eastern Ghats Belt, India, Geol. Soc. Am. Bull., 123, 2031-2049.

Breeding, C. M., J. J. Ague, M. Grove, and L. H. Rupke (2004), Isotopic and chemical alteration of zircon by metamorphic fluids: $\mathrm{U}-\mathrm{Pb}$ age depth-profiling of zircon crystals from Barrow's garnet zone, northeast Scotland, Am. Mineral., 89, 1067-1077.

Bromiley, G. D., and M. Hiscock (2016), Grain boundary diffusion of titanium in polycrystalline quartz and its implications for titanium in quartz (TitaniQ) geothermobarometry, Geochim. Cosmochim. Acta, 178, 281-290.

Brouand, M., G. Banzet, and P. Barbey (1990), Zircon behavior during crustal anatexis. Evidence from the Tibetan Slab migmatites (Nepal), J. Volcanol. Geotherm. Res., 44(1-2), 143-161.

Buick, I. S., J. Hermann, R. Maas, and R. L. Gibson (2006), The timing of sub-solidus hydrothermal alteration in the Central Zone, Limpopo Belt (South Africa): Constraints from titanite $\mathrm{U}-\mathrm{Pb}$ geochronology and REE partitioning, Lithos, 98, 97-117.

Carlson, W. D. (1999), The case against Ostwald ripening of porphyroblasts, Can. Mineral., 37(2), 403-413.

Carson, C. J., J. J. Ague, M. Grove, C. D. Coath, and T. M. Harrison (2002), U-Pb isotopic behaviour of zircon during upper-amphibolite facies fluid infiltration in the Napier Complex, east Antarctica, Earth Planet. Sci. Lett., 199, 287-310.

Carswell, D. A., R. D. Tucker, P. J. O'Brien, and T. E. Krogh (2003), Coesite micro-inclusions and the $\mathrm{U} / \mathrm{Pb}$ age of zircons from the Hareidland Eclogite in the Western Gneiss Region of Norway, Lithos, 67, 181-190.

Caruba, R., and P. Iacconi (1983), Les zircons des pegmatites de Narssârssuk (Groëland)-l'eau et les groupments $\mathrm{OH}$ dans les zircons metamictes, Chem. Geol., 38, 75-92.

Castelli, D., F. Rolfo, C. Groppo, and R. Compagnoni (2007), Impure marbles from the UHP Brossasco-Isasca Unit (DoraMaira Massif, western Alps): Evidence for Alpine equilibration 
in the diamond stability field and evaluation of the $\mathrm{X}\left(\mathrm{CO}_{2}\right)$ fluid evolution, J. Metamorph. Geol., 25(6), 587-603.

Chambers, J. A., and M. J. Kohn (2012), Titanium in muscovite, biotite, and hornblende: Modeling, thermometry and rutile activities in metapelites and amphibolites, Am. Mineral., 97, 543-555.

Cherniak, D. J., and E. B. Watson (2001), Pb diffusion in zircon, Chem. Geol., 172(1-2), 5-24.

Cherniak, D. J., and E. B. Watson (2007), Ti diffusion in zircon, Chem. Geol., 242, 473-486.

Cherniak, D. J., J. M. Hanchar, and E. B. Watson (1997), Rareearth diffusion in zircon, Chem. Geol., 134, 289-301.

Chopin, C. (1984), Coesite and pure pyrope in high-grade blueschists of the Western Alps: A first record and some consequences, Contrib. Mineral. Petrol., 86, 107-118.

Compagnoni, R., and T. Hirajima (2001), Superzoned garnets in the coesite-bearing Brossasco-Isasca unit, Dora-Maira massif, Western Alps, and the origin of the whiteschists, Lithos, 57, 219-236.

Cottle, J. M., M. S. A. Horstwood, and R. R. Parrish (2009), A new approach to single shot laser ablation analysis and its application to in situ $\mathrm{Pb} / \mathrm{U}$ geochronology, J. Anal. At. Spectrom., 24(10), 1355.

Crank, J. (1975), The Mathematics of Diffusion, pp. 414, Oxford University Press, London.

Daly, J. S. V., V. Balagansky, M. J. Timmerman, M. J. Whitehouse, K. de Jong, P. Guise, S. Bogdanova, R. Gorbatschev, and D. Bridgwater (2001), Ion microprobe $\mathrm{U}-\mathrm{Pb}$ zircon geochronology and isotopic evidence for a trans-crustal suture in the Lapland-Kola Orogen, northern Fennoscandian Shield, Precambrian Res., 105, 289-314.

Das, K., S. Bose, S. Karmakar, D. J. Dunkley, and S. Dasgupta (2011), Multiple tectonometamorphic imprints in the lower crust: First evidence of ca $950 \mathrm{Ma}$ (zircon U-Pb SHRIMP) compressional reworking of UHT aluminous granulites from the Eastern Ghats Belt, India, Geol. J., 46, 217-239.

Degeling, H., S. Eggins, and D. J. Ellis (2001), Zr budgets for metamorphic reactions, and the formation of zircon from garnet breakdown, Mineral. Mag., 65, 749-758.

Dempster, T., and P. Chung (2013), Metamorphic zircon: Tracking fluid pathways and the implications for the preservation of detrital zircon, J. Geol. Soc., 170(4), 631-639.

Dempster, T. J., D. C. Hay, and B. J. Bluck (2004), Zircon growth in slate, Geology, 32, 221-224.

Dempster, T. J., D. C. Hay, S. H. Gordon, and N. M. Kelly (2008), Micro-zircon: Origin and evolution during metamorphism, J. Metamorph. Geol., 26, 499-507.

Dobmeier, C. J., and M. M. Raith (2003), Crustal architecture and evolution of the Eastern Ghats Belt and adjacent regions of India, Geol. Soc. Lond. Spec. Publ., 206, 145-168.

Es'kova, E. M. (1959), Geochemistry of $\mathrm{Nb}$ and $\mathrm{Ta}$ in the nepheline syenite massifs of the Vishnevyie Mountains, Geokhimiya, 2, 130-139 (in Russian).

Ewing, T. A., J. Hermann, and D. Rubatto (2013), The robustness of the $\mathrm{Zr}$-in-rutile and Ti-in-zircon thermometers during high-temperature metamorphism (Ivrea-Verbano Zone, northern Italy), Contrib. Mineral. Petrol., 165(4), 757-779.

Ferrando, S., M. L. Frezzotti, M. Petrelli, and R. Compagnoni (2009), Metasomatism of continental crust during subduction:
The UHP whiteschists from the Southern Dora-Maira Massif (Italian Western Alps), J. Metamorph. Geol., 27, 739-756.

Ferry, J. M., and E. B. Watson (2007), New thermodynamic models and revised calibrations for the Ti-in-zircon and Zr-in-rutile thermometers, Contrib. Mineral. Petrol., 154, 429-437.

Finch, R. J., and J. M. Hanchar (2003), Structure and chemistry of zircon and zircon-group minerals, Rev. Mineral. Geochem., 53, 1-25.

Fraser, G., D. Ellis, and S. Eggins (1997), Zirconium abundance in granulite-facies minerals, with implications for zircon geochronology in high-grade rocks, Geology, 25, 607-610.

Frondel, C. (1953), Hydroxyl substitution in thorite and zircon, Am. Mineral., 38, 1007-1018.

Fu, B., F. Z. Page, A. J. Cavosie, J. Fournelle, N. T. Kita, J. S. Lackey, S. A. Wilde, and J. W. Valley (2008), Ti-in-zircon thermometry: Applications and limitations, Contrib. Mineral. Petrol., 156, 197-215.

Gauthiez-Putallaz, L., D. Rubatto, and J. Hermann (2016), Dating prograde fluid pulses during subduction by in situ $\mathrm{U}-\mathrm{Pb}$ and oxygen isotope analysis, Contrib. Mineral. Petrol., 171(2), 15.

Gebauer, D., H. P. Schertl, M. Brix, and W. Schreyer (1997), $35 \mathrm{Ma}$ old ultrahigh-pressure metamorphism and evidence for very rapid exhumation in the Dora Maira Massif, Western Alps, Lithos, 41, 5-24.

Geisler, T., R. T. Pidgeon, W. Van Bronswijk, and R. Pleysier (2001), Kinetics of thermal recovery and recrystallization of partially metamict zircon: A Raman spectroscopic study, Eur. J. Mineral., 13, 1163-1176.

Geisler, T., R. T. Pidgeon, R. Kurtz, W. Van Bronswijk, and H. Schleicher (2003), Experimental hydrothermal alteration of partially metamict zircon, Am. Mineral., 88 , 1496-1513.

Gerya, T. V., B. Stöckhert, and A. L. Perchuk (2002), Exhumation of high-pressure metamorphic rocks in a subduction channel: A numerical simulation, Tectonics, 21, doi:10.1029/2002TC001406.

Grew, E. S., and W. I. Manton (1986), A new correlation of sapphirine granulites in the Indo-Antarctic metamorphic terrane: Late Proterozoic dates from the Eastern Ghats, Precambrian Res., 33, 123-139.

Haifler, J., and J. Kotková (2016), UHP-UHT peak conditions and near-adiabatic exhumation path of diamond-bearing garnet-clinopyroxene rocks from the Eger Crystalline Complex, North Bohemian Massif, Lithos, 248-251, 366-381.

Hanchar, J. M., R. J. Finch, P. W. O. Hoskin, E. B. Watson, D. J. Cherniak, and A. N. Mariano (2001), Rare earth elements in synthetic zircon: Part 1. Synthesis, and rare earth and phosphorus doping, Am. Mineral., 86, 667-680.

Harley, S. L. (2008), Refining the P-T records of UHT crustal metamorphism, J. Metamorph. Geol., 26, 125-154.

Harley, S. L. (2016), A matter of time: The importance of the duration of UHT metamorphism, J. Mineral. Petrol. Sci., 111(2), 50-72, doi:10.2465/jmps.160128.

Harley, S. L., and L. P. Black (1997), A revised Archaean chronology for the Napier Complex, Enderby Land, from SHRIMP ion-microprobe studies, Antarct. Sci., 9, 74-91. 
Harley, S. L., and N. M. Kelly (2007), The impact of zircongarnet REE distribution data on the interpretation of zircon $\mathrm{U}-\mathrm{Pb}$ ages in complex high-grade terrains: An example from the Rauer Islands, East Antarctica, Chem. Geol., 241, 62-87.

Harley, S. L., and Y. Motoyoshi (2000), Al zoning in orthopyroxene in a sapphirine quartzite: Evidence for $>1,120 \_C$ UHT metamorphism in the Napier Complex, Antarctica, and implications for the entropy of sapphirine, Contrib. Mineral. Petrol., 138, 293-307.

Harley, S. L., and V. Nandakumar (2014), Accessory mineral behaviour in granulite migmatites: A case study from the Kerala Khondalite Belt, India, J. Petrol., 55, 1965-2002.

Harley, S. L., P. D. Kinny, I. Snape, and L. P. Black (2001), Zircon chemistry and the definition of events in Archaean granulite terrains, in Extended Abstracts of 4th International Archaean Symposium, edited by K. F. Cassidy, J. M. Dunphy, and M. J. van Kranendonk, pp. 511-513, AGSO Geoscience Australia Record 2001/37, Canberra.

Harrison, T. M., and E. B. Watson (1983), Kinetics of zircon dissolution and zirconium diffusion in granitic melts of variable water content, Contrib. Mineral. Petrol., 84, 66-72.

Hay, D. C., and T. J. Dempster (2009), Zircon behaviour during low-temperature metamorphism, J. Petrol., 50(4), 571-589.

Hermann, J. (2003), Experimental evidence for diamond-facies metamorphism in the Dora-Maira Massif, Lithos, 70, $163-182$.

Hermann, J., and D. Rubatto (2003), Relating zircon and monazite domains to garnet growth zones: Age and duration of granulite facies metamorphism in the Val Malenco lower crust, J. Metamorph. Geol., 21, 833-852.

Hermann, J., D. Rubatto, A. Korsakov, and V. S. Shatsky (2001), Multiple zircon growth during fast exhumation of diamondiferous, deeply subducted continental crust (Kokchetav Massif, Kazakhstan), Contrib. Mineral. Petrol., 141, 66-82.

Hiess, J., A. P. Nutman, V. C. Bennett, and P. Holden (2008), Ti-in-zircon thermometry applied to contrasting Archean metamorphic and igneous systems, Chem. Geol., 247, 323-338.

Hinton, R. W., and B. G. J. Upton (1991), The chemistry of zircon: Variations within and between large crystals from syenite and alkali basalt xenoliths, Geochim. Cosmochim. Acta, 55, 3287-3302.

Hinton R., R. Macdonald, D. MacGarvie, A. Tindle, and S. Harley (2003), The possible role of hydrogen in the substitution of rare earth elements into zircon (abstract), EGSAGU-EUG Joint Assembly, European Geophysical Society, Nice, p. 05968.

Hippe, K., A. Möller, A. von Quadt, I. Peytcheva, and K. Hammerschmidt (2016), Zircon geochronology of the Koraput alkaline complex: Insights from combined geochemical and $\mathrm{U}-\mathrm{Pb}-\mathrm{Hf}$ isotope analyses, and implications for the timing of alkaline magmatism in the Eastern Ghats Belt, India, Gondwana Res., 34, 205-220.

Hokada, T., and S. L. Harley (2004), Zircon growth in UHT leucosome: Constraints from zircon-garnet rare earth elements (REE) relations in Napier Complex, East Antarctica, J. Mineral. Petrol. Sci., 99, 180-190.

Hollis, J. A., and S. L. Harley (2002), New evidence for the peak temperatures and the near-peak pressure-temperature evolution of the Napier Complex, in Proceedings of the 8th International Symposium on Antarctic Earth Sciences, edited by J. A. Gamble, D. N. B. Skinner, and S. Henrys, pp. 19-30, The Royal Society of New Zealand, Wellington.

de Hoog, J. C. M., C. J. Lissenberg, R. A. Brooker, R. Hinton, D. Trail, E. Hellebrand, and EIMF (2014), Hydrogen incorporation and charge balance in natural zircon, Geochim. Cosmochim. Acta, 141, 472-486.

Hoskin, P. W. O., and L. P. Black (2000), Metamorphic zircon formation by solid-state recrystallization of protolith igneous zircon, J. Metamorph. Geol., 18, 423-439.

Kaneko, Y., S. Maruyama, M. Terabayashi, H. Yamamoto, M. Ishikawa, R. Anma, C. D. Parkinson, T. Ota, Y. Nakajima, I. Katayama, J. Yamamoto, and K. Yamauchi (2000), Geology of the Kokchetav UHP-HP metamorphic belt, northern Kazakhstan, Island Arc, 9, 264-283.

Kaneko, Y., I. Katayama, H. Yamamoto, K. Misawa, M. Ishikawa, H. U. Rehman, A. B. Kausar, and K. Shiraishi (2003), Timing of Himalayan ultrahigh-pressure metamorphism: Sinking rate and subduction angle of the Indian continental crust beneath Asia, J. Metamorph. Geol., 21(6), 589-599.

Katayama, I., and S. Maruyama (2009), Inclusion study in zircon from ultrahigh-pressure metamorphic rocks in the Kokchetav massif: An excellent tracer of metamorphic history, J. Geol. Soc., 166(4), 783-796.

Katayama, I., S. Maruyama, C. D. Parkinson, K. Terada, and Y. Sano (2001), Ion micro-probe U-Pb zircon geochronology of peak and retrograde stages of ultrahigh-pressure metamorphic rocks from the Kokchetav Massif, northern Kazakhstan, Earth Planet. Sci. Lett., 188(1-2), 185-198.

Kelly, N. M., and S. L. Harley (2005), An integrated textural and chemical approach to zircon geochronology: Refining the Archaean history of the Napier Complex, east Antarctica, Contrib. Mineral. Petrol., 149, 57-84.

Kelly, N. M., G. L. Clarke, and C. M. Fanning (2004), Archaean crust in the Rayner Complex of east Antarctica: Oygarden Group of Islands, Kemp Land, Trans. R. Soc. Edinb. Earth Sci., 95, 491-510.

Kelly, N. M., R. W. Hinton, S. L. Harley, and S. K. Appleby (2008), New SIMS U-Pb zircon ages from the Langavat Belt, South Harris, NW Scotland: implications for the Lewisian Terrane Model, J. Geol. Soc. Lond., 165, 967-981.

Kelly, N. M., B. P. Gorman, R. W. Hinton, and S. L. Harley (2010), Mobilization of $\mathrm{Pb}$ in zircon during high-T metamorphism (abstract), 2010 American Geophysical Union Fall Meeting, 13-17 December 2010, San Francisco, CA.

Kelsey, D. E., and R. Powell (2011), Progress in linking accessory mineral growth and breakdown to major mineral evolution in metamorphic rocks: A thermodynamic approach in the $\mathrm{Na}{ }_{2} \mathrm{O}-\mathrm{CaO}-\mathrm{K}_{2} \mathrm{O}-\mathrm{FeO}-\mathrm{MgO}-\mathrm{Al}_{2} \mathrm{O}_{3}-\mathrm{SiO}_{2}-\mathrm{H}_{2} \mathrm{O}-\mathrm{TiO}_{2}-\mathrm{ZrO}_{2}$ system, J. Metamorph. Geol., 29, 151-166.

Kelsey, D. E., C. Clark, and M. Hand (2008), Thermobarometric modelling of zircon and monazite growth in melt-bearing systems: Examples using model metapelitic and metapsammitic granulites, J. Metamorph. Geol., 26, 199-212.

Kirkland, C. L., R. H. Smithies, R. J. M. Taylor, N. Evans, and B. McDonald (2015), Zircon Th/U ratios in magmatic environs, Lithos, 212-215, 397-414. 
Koepke, J., and H. Behrens (2001), Trace element diffusion in andesitic melts: An application of synchrotron X-ray fluorescence analysis, Geochim. Cosmochim. Acta, 65, 1481-1498.

Kohn, M. J. (1993), Modeling of prograde mineral $\delta^{18} \mathrm{O}$ changes in metamorphic systems, Contrib. Mineral. Petrol., 113, 24-39.

Kohn, M. J. (2009), Models of garnet differential geochronology, Geochim. Cosmochim. Acta, 73, 170-182.

Kohn, M. J. (2014), Himalayan Metamorphism and Its Tectonic Implications, Ann. Rev. Earth Planet. Sci., 42, 381-419.

Kohn, M. J. (2016), Metamorphic chronology - A tool for all ages: Past achievements and future prospects, Am. Mineral., 101, 25-42.

Kohn, M. J., and J. W. Valley (1998a), Obtaining equilibrium oxygen isotope fractionations from rocks: Theory and examples, Contrib. Mineral. Petrol., 132(3), 209-224.

Kohn, M. J., and J. W. Valley (1998b), Oxygen isotope geochemistry of the amphiboles: Isotope effects of cation substitutions in minerals, Geochim. Cosmochim. Acta, 62(11), 1947-1958.

Kohn, M. J., J. W. Valley, D. Elsenheimer, and M. J. Spicuzza (1993), O isotope zoning in garnet and staurolite: Evidence for closed system mineral growth during regional metamorphism, Am. Mineral., 78, 988-1001.

Kohn, M. J., S. L. Corrie, and C. Markley (2015), The fall and rise of metamorphic zircon, Am. Mineral., 100, 897-908.

Kohn, M. J., S. C. Penniston-Dorland, and J. C. S. Ferreira (2016), Implications of near-rim compositional zoning in rutile for geothermometry, geospeedometry, and trace element equilibration, Contrib. Mineral. Petrol., 171, 78, doi:10.1007/s00410-016-1285-1.

Kooijman, E., M. A. Smit, K. Mezger, and J. Berndt (2012), Trace element systematics in granulite facies rutile: Implications for $\mathrm{Zr}$ geothermometry and provenance studies, J. Metamorph. Geol., 30(4), 397-412.

Korhonen, F. J., A. K. Saw, C. Clark, M. Brown, and S. Bhattacharya (2011), New constraints on UHT metamorphism in the Eastern Ghats Province through the application of phase equilibria modelling and in situ geochronology, Gondwana Res., 20, 764-781.

Korhonen, F. J., C. Clark, M. Brown, S. Bhattacharya, and R. Taylor (2013), How long-lived is ultrahigh temperature (UHT) metamorphism? Constraints from zircon and monazite geochronology in the Eastern Ghats orogenic belt, India, Precambrian Res., 234, 322-350.

Kotková, J., M. Whitehouse, U. Schaltegger, and F.-X. D. D'Abzac (2016), The fate of zircon during UHT-UHP metamorphism: Isotopic $\left(\mathrm{U} / \mathrm{Pb}, \delta^{18} \mathrm{O}, \mathrm{Hf}\right)$ and trace element constraints, J. Metamorph. Geol., 34, 719-739.

Kriegsman, L. M. (2001), Partial melting, partial melt extraction and partial back reaction in anatectic migmatites, Lithos, 56, 75-96.

Kriegsman, L. M., and A. M. Álvarez-Valero (2010), Meltproducing versus melt-consuming reactions in pelitic xenoliths and migmatites, Lithos, 116(3-4), 310-320.

Kusiak, M. A., M. J. Whitehouse, S. A. Wilde, A. A. Nemchin, and C. Clark (2013a), Mobilization of radiogenic $\mathrm{Pb}$ in zircon revealed by ion imaging: Implications for early Earth geochronology, Geology, 41, 291-294.
Kusiak, M. A., M. J. Whitehouse, S. A. Wilde, D. J. Dunkley, M. Menneken, A. A. Nemchin, and C. Clark (2013b), Changes in zircon chemistry during archean UHT metamorphism in the Napier Complex, Antarctica, Am. J. Sci., 313, 933-967.

Kusiak, M. A., D. J. Dunkley, R. Wirth, M. J. Whitehouse, and S. A. Wilde (2015), Metallic lead nanospheres discovered in ancient zircons, Proc. Natl. Acad. Sci. U. S. A., 112, 4958-4963.

Liati, A., T. Theye, C. M. Fanning, D. Gebauer, and N. Rayner (2016), Multiple subduction cycles in the Alpine orogeny, as recorded in single zircon crystals (Rhodope zone, Greece), Gondwana Res., 29(1), 199-207.

Liermann, H.-P., C. Isachsen, U. Altenberger, and R. Oberhänsli (2002), Behavior of zircon during high-pressure, low-temperature metamorphism: Case study from the Internal Unit of the Sesia Zone (Western Italian Alps), Eur. J. Mineral., 14, 61-71.

Lifshitz, I. M., and V. V. Slyozov (1961), The kinetics of precipitation from supersaturated solid solutions, J. Phys. Chem. Solids, 19, 35-50.

Liou, J. G., R. Y. Zhang, W. G. Ernst, D. Rumble III, and S. Maruyama (1998), High-pressure minerals from deeply subducted metamorphic rocks, Rev. Mineral., 37, 33-96.

Liou, J. G., R. Zhang, F. Liu, Z. Zhang, and W. G. Ernst (2012), Mineralogy, petrology, $\mathrm{U}-\mathrm{Pb}$ geochronology, and geologic evolution of the Dabie-Sulu classic ultrahigh-pressure metamorphic terrane, East-Central China, Am. Mineral., 97(10), 1533-1543.

Liu, F. I., and J. G. Liou (2011), Zircon as the best mineral for P-T-time history of UHP metamorphism: A review on mineral inclusions and U-Pb SHRIMP ages of zircons from the Dabie-Sulu UHP rocks, J. Asia Earth Sci., 40, 1-39.

Liu, Y.-C., S.-G. Li, and S.-T. Xu (2007), Zircon SHRIMP U-Pb dating for gneisses in northern Dabie high T/P metamorphic zone, central China: Implications for decoupling within subducted continental crust, Lithos, 96, 170-185.

Massonne, H.-J. (2001), First find of coesite in the ultrahighpressure metamorphic region of the Central Erzgebirge, Germany, Eur. J. Mineral., 13, 565-570.

McClelland, W. C., S. E. Power, J. A. Gilotti, F. K. Mazdab, and B. Wopenka (2006), U-Pb SHRIMP geochronology and trace element geochemistry of coesite-bearing zircons, North-East Greenland Caledonides, Geol. Soc. Am. Spec. Pap., 403, 23-43.

Meldrum, A., L. A. Boatner, S. J. Zinkle, S.-X. Wang, L.-M. Wang, and R. C. Ewing (1999), Effects of dose rate and temperature on the crystalline-to-metamict transformation in the $\mathrm{ABO}_{4}$ orthosilicates, Can. Mineral., 37, 207-221.

Meyer, M., T. John, S. Brandt, and R. Klemd (2011), Trace element composition of rutile and the application of $\mathrm{Zr}$ in-rutile thermometry to UHT metamorphism (Epupa Complex, NW Namibia), Lithos, 126(3-4), 388-401.

Miyazaki, K. (1996), A numerical simulation of textural evolution due to Ostwald ripening in metamorphic rocks: A case for small amount of volume of dispersed crystals, Geochim. Cosmochim. Acta, 60, 277-290. 
Möller, A., and A. Kennedy (2006), Extremely high Th/U in metamorphic zircon: In situ dating of the Labwor Hills granulites, Geochim. Cosmochim. Acta, 70, A425.

Möller, A., P. J. O’Brien, A. Kennedy, and A. Kröner (2002), Polyphase zircon in ultrahigh-temperature granulites (Rogaland, SW Norway): Constraints for $\mathrm{Pb}$ diffusion in zircon, J. Metamorph. Geol., 20, 727-740.

Möller, A., P. J. O'Brien, A. Kennedy, and A. Kröner (2003), Linking growth episodes of zircon and metamorphic textures to zircon chemistry: An example from the ultrahigh temperature granulites of Rogaland (SW Norway), Geol. Soc. Lond. Spec. Publ., 220, 65-81.

Montel, J.-M. (1993), A model for monazite/melt equilibrium and application to the generation of granitic magmas, Chem. Geol., 110, 127-146.

Nasdala, L., and H. J. Massonne (2000), Microdiamonds from the Saxonian Erzgebirge, Germany: In situ micro-Raman characterisation, Eur. J. Mineral., 12, 495-498.

Nasdala, L., M. Wenzel, G. Vavra, G. Irmer, T. Wenzel, and B. Kober (2001), Metamictisation of natural zircon: Accumulation versus thermal annealing of radioactivityinduced damage, Contrib. Mineral. Petrol., 141(2), 125-144.

Nasdala, L., G. Irmer, and R. Jonckheere (2002), Radiation damage ages: Practial concept of impracticalvision? Reply to two comments on "Metamictisation of natural zircon: Accumulation versus thermal annealing of radioactivityinduced damate," and further discussion, Contrib. Mineral. Petrol., 143, 758-765.

Nemchin, A. A., L. M. Giannini, S. Bodorkos, and N. H. S. Oliver (2001), Ostwald ripening as a possible mechanism for zircon overgrowth formation during anatexis; theoretical constraints, a numerical model, and its application to pelitic migmatites of the Tickalara Metamorphics, northwestern Australia, Geochim. Cosmochim. Acta, 65(16), 2771-2788.

Okay, A. I. (1993), Petrology of a diamond and coesite-bearing metamorphic terrain: Dabie Shan, China, Eur. J. Mineral., 5, 659-673.

Ostwald, W. (1897), Studien über die Bildung und Umwandlung fester Körper [Studies on the formation and transformation of solid bodies], Z. Phys. Chem., 22, 289-330.

Pape, J., K. Mezger, and M. Robyr (2016), A systematic evaluation of the $\mathrm{Zr}$-in-rutile thermometer in ultra-high temperature (UHT) rocks, Contrib. Mineral. Petrol., 171(5), 1-5.

Parkinson, C. D., and I. Katayama (1999), Present-day ultrahigh-pressure conditions of coesite inclusion in zircon and garnet: Evidence from laser Raman microspectroscopy, Geology, 27, 979-982.

Parkinson, C. D., I. Katayama, J. G. Liou, and S. Maruyama (2002), The Diamond-Bearing Kokchetav Massif, Kazakhstan - Petrochemistry and Tectonic Evolution of an Unique Ultrahigh Pressure Metamorphic Terrane, pp. 527, Universal Academy Press, Tokyo.

Pawlig, S., and L. P. Baumgartner (2001), Geochemistry of a talc-kyanite-chloritoid shear zone within the Monte Rosa granite, Val d'Ayas, Italy, Schweiz. Mineral. Petrogr. Mitt., 81, 329-346.

Peck, W. H., M. E. Bickford, J. M. McLelland, A. N. Nagle, and G. J. Swarr (2010), Mechanism of metamorphic zircon growth in a granulite-facies quartzite, Adirondack Highlands, Grenville Province, New York, Am. Mineral., 95(11-12), 1796-1806.

Pettke, T., A. Audétat, U. Schaltegger, and C. A. Heinrich (2005), Magmatic-to-hydrothermal evolution in the W-Sn mineralized Mole Granite (NSW, Australia) part II: Evolving zircon and thorite trace element chemistry, Chem. Geol., 220, 191-213.

Pidgeon, R. T. (1992), Recrystallisation of oscillatory zoned zircon: Some geochronological and petrological implications, Contrib. Mineral. Petrol., 110, 463-472.

Pidgeon, R. T. (2014), Zircon radiation damage ages, Chem. Geol., 367, 13-22.

Putnis, A. (2002), Mineral replacement reactions: From macroscopic observations to microscopic mechanisms, Mineral. Mag., 66, 689-708.

Rasmussen, B. (2005a), Zircon growth in very low grade metasedimentary rocks: Evidence for zirconium mobility at $\sim 250^{\circ} \mathrm{C}$, Contrib. Mineral. Petrol., 150(2), 146-155.

Rasmussen, B. (2005b), Radiometric dating of sedimentary rocks: The application of diagenetic xenotime geochronology, Earth Sci. Rev., 68(3-4), 197-243.

Rickers, K., K. Mezger, and M. M. Raith (2001), Evolution of the continental crust in the Proterozoic Eastern Ghats Belt, and new constraints for Rodinia reconstruction: Implications from $\mathrm{Sm}-\mathrm{Nd}, \mathrm{Rb}-\mathrm{Sr}$ and $\mathrm{Pb}-\mathrm{Pb}$ isotopes, Precambrian Res., $112,183-212$.

Rizvanova, N. G., O. A. Levchenkov, A. E. Belous, N. I. Bezmen, A. V. Maslenikov, A. N. Komarov, A. F. Makeev, and L. K. Levskiy (2000), Zircon reaction and stability of the $\mathrm{U}-\mathrm{Pb}$ isotope system during interaction with carbonate fluid: Experimental hydrothermal study, Contrib. Mineral. Petrol., 139(1), 101-114.

Roberts, M. P., and F. Finger (1997), Do U-Pb zircon ages from granulites reflect peak metamorphic conditions? Geology, 25, 319-322.

Rubatto, D. (2002), Zircon trace element geochemistry: Partitioning with garnet and link between $\mathrm{U}-\mathrm{Pb}$ ages and metamorphism, Chem. Geol., 184, 123-138.

Rubatto, D. (2017), Zircon: The metamorphic mineral, Rev. Mineral. Geochem., 83, 261-296.

Rubatto, D., and J. Hermann (2003a), Zircon behaviour in deeply subducted rocks, Elements, 3, 31-35.

Rubatto, D., and J. Hermann (2003b), Zircon formation during fluid circulation in eclogites (Monviso, Western Alps): Implications for $\mathrm{Zr}$ and $\mathrm{Hf}$ budget in subduction zones, Geochim. Cosmochim. Acta, 67, 2173-2187.

Rubatto, D., and J. Hermann (2007), Experimental zircon/melt and zircon/garnet trace element partitioning and implications for the geochronology of crustal rocks, Chem. Geol., 241, 38-61.

Schertl, H.-P., and W. Schreyer (1996), Mineral inclusions in heavy minerals of the ultra-high pressure metamorphic rocks of the Dora Maira Massif and their bearing on the relative timing of the petrological events, Geophys. Monogr., 95, 331-342.

Schertl, H. P., W. Schreyer, and C. Chopin (1991), The pyropecoesite rocks and their country rocks at Parigi, Dora Maira Massif, western Alps: Detailed petrography, mineral chemistry and P-T path, Contrib. Mineral. Petrol., 108, 1-21. 
Schmidt, C. (2006), Low-temperature Zr mobility: An in situ synchrotron-radiation XRF study of the effect of radiation damage in zircon on the element release in $\mathrm{H} 2 \mathrm{O}+\mathrm{HCl} \mathrm{SiO}{ }_{2}$ fluids, Am. Mineral., 91(8-9), 1211-1215.

Shatsky, V. S., E. Jagoutz, N. V. Sobolev, O. A. Koz'menko, V. S. Parkhomenko, and M. Troesch (1999), Geochemistry and age of ultrahigh pressure metamorphic rocks from the Kokchetav massif (Northern Kazakhstan), Contrib. Mineral. Petrol., 137, 185-205.

Simmat, R., and M. M. Raith (2008), U-Th-Pb monazite geochronometry of the Eastern Ghats Belt, India: Timing and spatial disposition of poly-metamorphism, Precambrian Res., 162, 16-39.

Sinha, A. K., D. M. Wayne, and D. A. Hewitt (1992), The hydrothermal stability of zircon: Preliminary experimental and isotopic studies, Geochim. Cosmochim. Acta, 56, 3551-3560.

Smith, D. C., and G. Godard (2013), A Raman spectroscopic study of diamond and disordered sp3-carbon in the coesitebearing Straumen Eclogite Pod, Norway, J. Metamorph. Geol., 31, 19-33.

Sobolev, N. V., and V. S. Shatsky (1990), Diamond inclusions in garnets from metamorphic rocks: A new environment for diamond formation, Nature, 343(6260), 742-746.

Sousa, J. L., M. J. Kohn, M. D. Schmitz, C. J. Northrup, and F. S. Spear (2013), Strontium isotope zoning in garnets: Implications for metamorphic matrix equilibration, geochronology, and phase equilibrium modeling, J. Metamorph. Geol., 31, 437-452.

Speer, J. A. (1982), Zircon, Rev. Mineral. Geochem., 5, 67-112.

Stepanov, A. S., D. Rubatto, J. Hermann, and A. V. Korsakov (2016), Contrasting P-Tpaths within the Barchi-Kol UHP terrain (Kokchetav Complex): Implications for subduction and exhumation of continental crust, Am. Mineral., 101(4), 788-807.

Tabata, H., K. Yamauchi, S. Maruyama, and J. G. Liou (1998), Tracing the extent of an ultrahigh pressure metamorphic terrane: A mineral inclusion study of zircons and gneisses from the Dabie Mountains, in When Continents Collide: Geodynamics and Geochemistry of Ultrahigh-Pressure Rocks, edited by B. Hacker and J. G. Liou, pp. 261-274, Kluwer, Dordrecht.

Taylor, R. J. M., S. L. Harley, R. W. Hinton, S. Elphick, C. Clark, and N. M. Kelly (2015), Experimental determination of REE partition coefficients between zircon, garnet and melt: A key to understanding high-T crustal processes, J. Metamorph. Geol., 33, 231-248.

Taylor-Jones, K., and R. Powell (2015), Interpreting zirconiumin-rutile thermometric results, J. Metamorph. Geol., 33(2), $115-122$.

Thomas, J. B., E. B. Watson, F. S. Spear, F. S. Shemella, S. K. Nayak, and A. Lanzirotti (2010), TitaniQ under pressure: The effect of pressure and temperature on the solubility of Ti in quartz, Contrib. Mineral. Petrol., 160, 743-759.

Tomaschek, F., A. K. Kennedy, I. M. Villa, M. Lagos, and C. Ballhaus (2003), Zircons from Syros, Cyclades, Greece - Recrystallization and mobilization of zircon during high-pressure metamorphism, J. Petrol., 44, 1977-2002.

Trail, D., J. B. Thomas, and E. B. Watson (2011), The incorporation of hydroxyl into zircon, Am. Mineral., 96, 60-67.
Trail, D., E. B. Watson, and N. D. Tailby (2012), Ce and Eu anomalies in zircon as proxies for the oxidation state of magmas, Geochim. Cosmochim. Acta, 97, 70-87.

Trail, D., D. J. Cherniak, E. B. Watson, T. M. Marrison, B. P. Weiss, and I. Szumila (2016), Li zoning in zircon as a potential geospeedometer and peak temperature indicator, Contrib. Mineral. Petrol., 171, 25, doi:10.1007/s00410-016-1238-8.

Tsujimori, T., J. G. Liou, J. Wooden, and T. Miyamoto (2005), $\mathrm{U}-\mathrm{Pb}$ dating of large zircons in low-temperature jadeititie from the Osayama serpentinite Mélange, southwest Japan: Insights into the timing of serpentinization, Int. Geol. Rev., 47, 1048-1057.

Tuisku, P., and H. Huhma (1999), SIMS U-Pb dating of zircons from migmatite khondalites and enderbite from Lapland granulite belt, Finland, Terra Abstracts, 11, 710-711.

Tuisku, P., and H. Huhma (2006), Evolution of migmatitic granulite complexes: Implications from lapland granulite belt, part II: Isotopic dating, Bull. Geol. Soc. Finl., 78, 143-175.

Tuisku, P., P. Mikkola, and H. Huhma (2006), Evolution of migmatitic granulite complexes: Implications from lapland granulite belt, part I: Metamorphic geology, Bull. Geol. Soc. Finl., 78, 71-105.

Valley, J. W., and N. T. Kita (2009), In situ oxygen isotope geochemistry by ion microprobe, Mineralogical Association of Canada, Short Course 41, pp. 19-63.

Valley, J. W., I. N. Bindeman, and W. H. Peck (2003), Empirical calibration of oxygen isotope fractionation in zircon, Geochim. Cosmochim. Acta, 67(17), 3257-3266.

Valley, J. W., A. J. Cavosie, T. Ushikubo, D. A. Reinhard, D. F. Lawrence, D. J. Larson, P. H. Clifton, T. F. Kelly, S. A. Wilde, D. E. Moser, and M. J. Spicuzza (2014), Hadean age for a post-magma-ocean zircon confirmed by atom-probe tomography, Nat. Geosci., 7, 219-223.

Vorhies, S. H., J. J. Ague, and A. K. Schmitt (2013), Zircon growth and recrystallization during progressive metamorphism, Barrovian zones, Scotland, Am. Mineral., 98, 219-230.

Wagner, C. (1961), Theorie der Alterung von Niederschlagen durch Umlosen, Z. Elektrochem., 64, 581-591.

Wang, X., J. G. Liou, and H. K. Mao (1989), Coesite-bearing eclogite from the Dabie Mountains in central China, Geology, 17, 1085-1088.

Wang, X., W. L. Griffin, J. Chen, P. Huang, and X. Li (2011), $\mathrm{U}$ and $\mathrm{Th}$ contents and $\mathrm{Th} / \mathrm{U}$ ratios of zircon in felsic and mafic magmatic rocks: Improved zircon-melt distribution coefficients, Acta Geol. Sin., 85, 164-174.

Warren, C. J., C. Beaumont, and R. A. Jamieson (2008), Formation and exhumation of ultra-high-pressure rocks during continental collision: Role of detachment in the subduction channel, Geochem. Geophys. Geosyst., 9(4), doi:10.1029/2007GC001839.

Watson, E. B., and T. M. Harrison (1983), Zircon saturation revisited; temperature and composition effects in a variety of crustal magma types, Earth Planet. Sci. Lett., 64(2), 295-304.

Watson, E. B., D. A. Wark, and J. B. Thomas (2006), Crystallization thermometers for zircon and rutile, Contrib. Mineral. Petrol., 151, 413-433. 
Whitehouse, M. J., and J. P. Platt (2003), Dating high-grade metamorphism - Constraints from rare-earth elements in zircon and garnet, Contrib. Mineral. Petrol., 145, 61-74.

Wilke, M., C. Schmidt, J. Dubrail, K. Appel, M. Borchert, K. Kvashnina, and C. E. Manning (2012), Zircon solubility and zirconium complexation in $\mathrm{H}_{2} \mathrm{O}+\mathrm{Na}_{2} \mathrm{O}+\mathrm{SiO}_{2} \pm \mathrm{Al}_{2} \mathrm{O}_{3}$ fluids at high pressure and temperature, Earth Planet. Sci. Lett., 349-350, 15-25.

Williams, I. S. (2001), Response of detrital zircon and monazite, and their $\mathrm{U}-\mathrm{Pb}$ isotopic systems, to regional metamorphism and host-rock partial melting, Cooma Complex, southeastern Australia, Aust. J. Earth Sci., 48, 557-580.

Williams, I. S., I. S. Buick, and I. Cartwright (1996), An extended episode of early Mesoproterozoic fluid flow in the Reynolds Range, central Australia, J. Metamorph. Geol., 14, $29-47$.

Xie, L., R. Wang, X. Chen, J. Qiu, and D. Wang (2005), Th-rich zircon from peralkaline A-type granite: Mineralogical features and petrological implications, Chin. Sci. Bull., 50, 809-817.
Xu, S., A. I. Okay, S. Ji, A. M. C. Sengör, W. Su, Y. Liu, and L. Jiang (1992), Diamond from the Dabie Shan metamorphic rocks and its implication for tectonic setting, Science, 256, 80-82.

Yakymchuk, C., and M. Brown (2014), Behaviour of zircon and monazite during crustal melting, J. Geol. Soc. Lond., 171, 465-479.

Zhang, R. Y., J. G. Liou, W. G. Ernst, R. G. Coleman, N. V. Sobolev, and V. S. Shatsky (1997), Metamorphic evolution of diamond-bearing and associated rocks from the Kokchetav Massif, northern Kazakhstan, J. Metamorph. Geol., 15(4), 479-496.

Zhang, Z., K. Shen, Y. Xiao, J. Hoefs, and J. Liou (2006), Mineral and fluid inclusions in zircon of UHP metamorphic rocks from the CCSD-main drill hole: A record of metamorphism and fluid activity, Lithos, 92(3-4), 378-398.

Zhang, Z.-m., K. Shen, J.-1. Wang, and H.-1. Dong (2009), Petrological and geochronological constraints on the formation, subduction and exhumation of the continental crust in the southern Sulu orogen, eastern-central China, Tectonophysics, 475(2), 291-307. 